\title{
Experimental Results: Pilot Plant Calcine Dissolution and Liquid Feed Stability
}

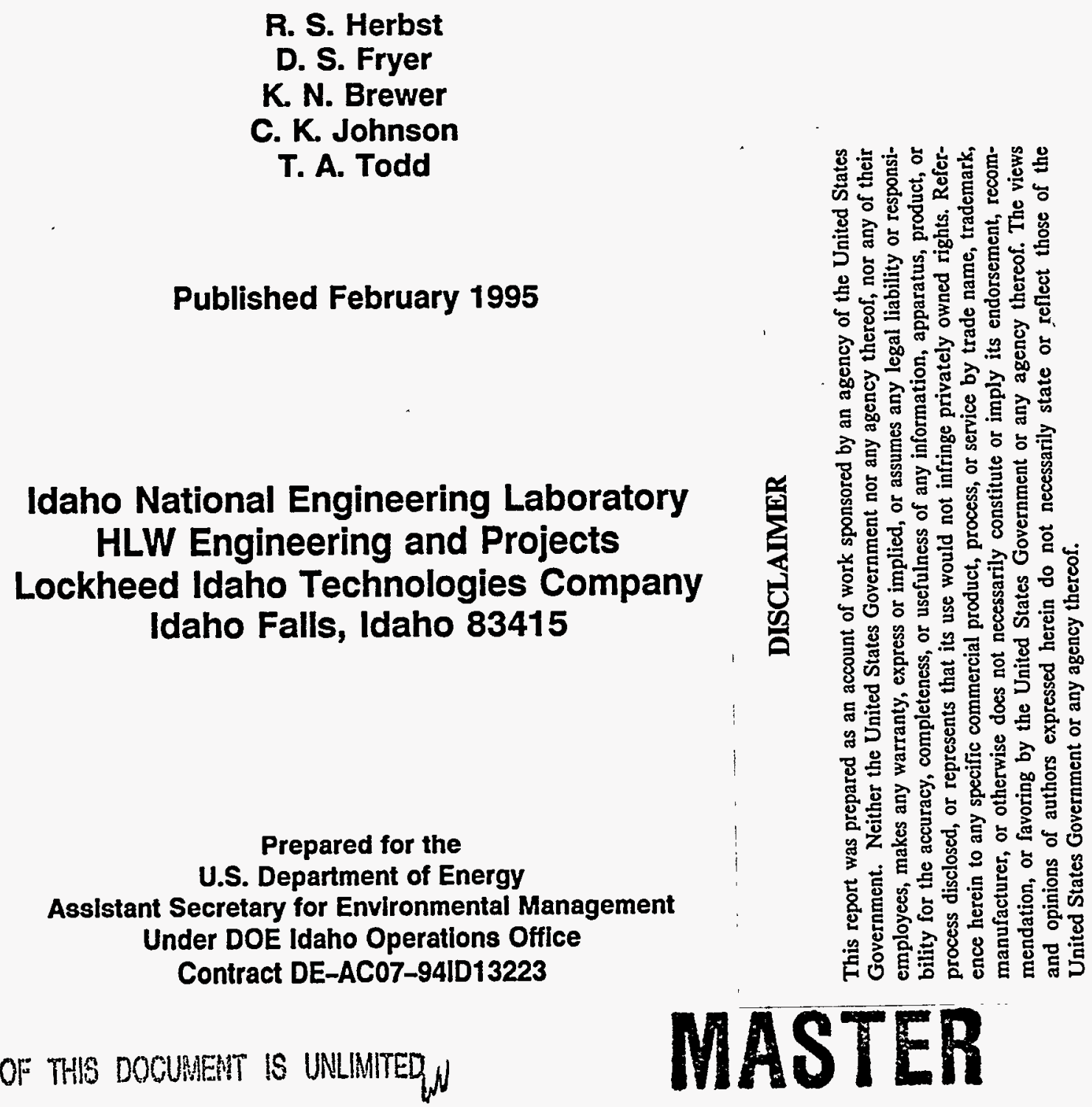




\section{DISCLAIMER}

Portions of this document may be illegible in electronic image products. Images are produced from the best available original document. 


\begin{abstract}
The dissolution of simulated Idaho Chemical Processing Plant pilot plant calcines, containing none of the radioactive actinides, lanthanides or fission products, was examined to evaluate the solubility of calcine matrix materials in acidic media. This study was a necessary precursor to dissolution and optimization experiments with actual radionuclide-containing calcines. The importance of temperature, nitric acid concentration, ratio of acid volume to calcine mass, and time on the amount, as a weight percentage of calcine dissolved, was evaluated. These parameters were studied for several representative pilot plant calcine types: 1) Run \#74 Zirconia calcine; 2) Run \#17 Zirconia/Sodium calcine; 3) Run \#64 Zirconia/Sodium calcine; 3) Run \#1027 Alumina calcine; and, 4) Run \#20 Alumina/Zirconia/Sodium calcine.

Statistically designed experiments with the different pilot plant calcines indicated the effect of the studied process variables on the amount of calcine dissolved decreases in the order:

\section{Acid/Calcine Ratio $>$ Temperature $>\mathrm{HNO}_{3}$ Concentration $>$ Dissolution Time}

This trend ranks the importance of the four process variables and is consistent for each of the five different pilot plant calcines studied. The following conditions are suitable to achieve greater than $90 \mathrm{wt}$. \% dissolution of most $\mathrm{Zr}$, Al, or $\mathrm{Na}$ blend calcines:

1) Maximum nitric acid concentration of $5 \underline{M}$

2) Minimum acid/calcine ratio of $10 \mathrm{~mL}$ acid/1 gram calcine

3) Minimum dissolution temperature of $90^{\circ} \mathrm{C}$

4) Minimum dissolution time of 30 minutes

It may be possible to combine the first two conditions and specify only the moles of acid required per weight calcine dissolved. Slightly more acid is anticipated to be required for dissolution of alumina calcine types than for the zirconia calcine types. There appears to be no advantage for using $\mathrm{HF}$ in the initial dissolver solution as the amount of dissolution is decreased compared with using only $\mathrm{HNO}_{3}$.

The formation of calcium sulphate $\left(\mathrm{CaSO}_{4}\right)$ precipitates was observed in certain dissolved calcine solutions during the dissolution experiments. Consequently, a study was initiated to evaluate if and under what conditions the resulting dissolved calcine solutions would be unstable with regards to precipitate formation. The results indicate that precipitate formation in the calcine solutions prepared under the above proposed dissolution conditions are not anticipated. 
C1

. 


\section{TABLE OF CONTENTS}

ABSTRACT $\ldots \ldots \ldots \ldots \ldots \ldots \ldots \ldots \ldots \ldots \ldots \ldots \ldots \ldots \ldots \ldots \ldots \ldots \ldots$

LIST OF TABLES $\ldots \ldots \ldots \ldots \ldots \ldots \ldots \ldots \ldots \ldots \ldots \ldots \ldots \ldots \ldots \ldots$

LIST OF FIGURES $\ldots \ldots \ldots \ldots \ldots \ldots \ldots \ldots \ldots \ldots \ldots \ldots \ldots \ldots \ldots \ldots$

INTRODUCTION $\ldots \ldots \ldots \ldots \ldots \ldots \ldots \ldots \ldots \ldots \ldots \ldots \ldots \ldots \ldots \ldots \ldots$

BACKGROUND $\ldots \ldots \ldots \ldots \ldots \ldots \ldots \ldots \ldots \ldots \ldots \ldots \ldots \ldots \ldots \ldots \ldots$

PART I: PILOT PLANT CALCINE DISSOLUTION STUDIES $\ldots \ldots \ldots \ldots \ldots \ldots \ldots \ldots$

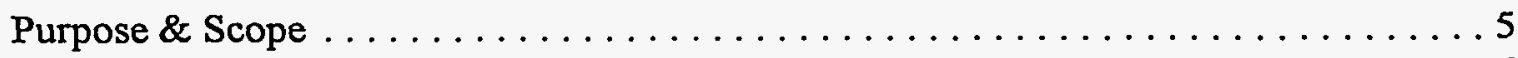

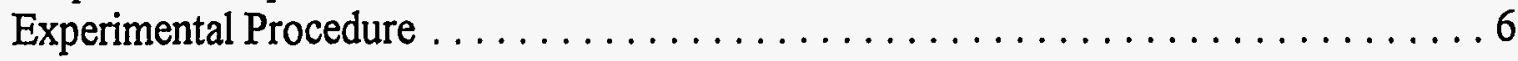

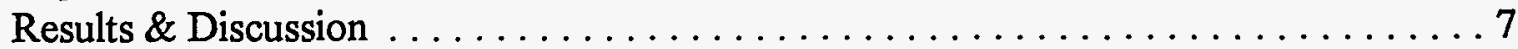

Statistically Designed Dissolution Experiments $\ldots \ldots \ldots \ldots \ldots \ldots \ldots \ldots$

Effect of HF on Dissolution of $\mathrm{Zr}$ Calcine . . . . . . . . . . . . . 14

Characterization of Liquids and Undissolved Solids $\ldots \ldots \ldots \ldots \ldots \ldots$

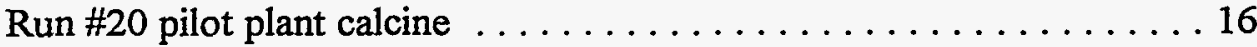

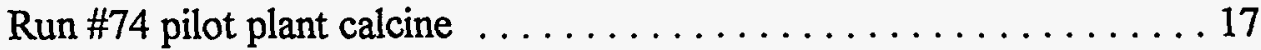

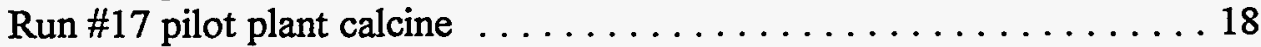

Run \#64 pilot plant calcine . . . . . . . . . . . . . . . . 19

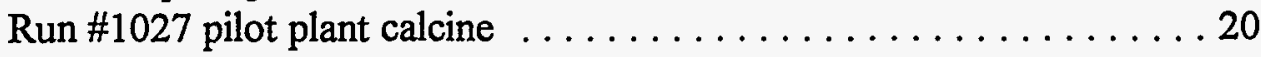

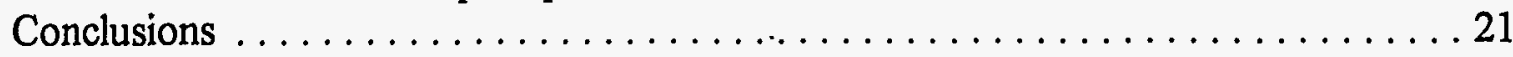

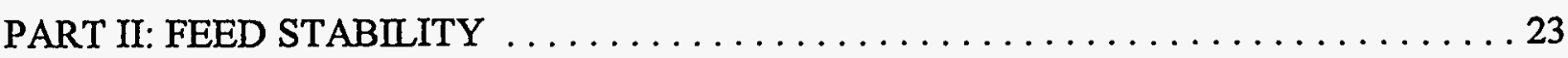

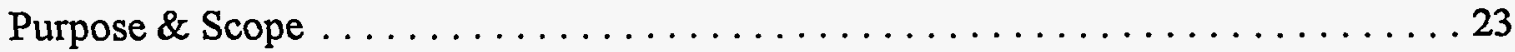

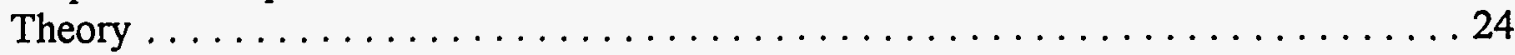

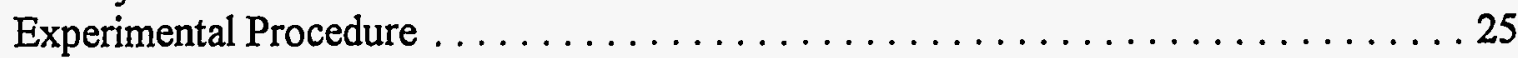

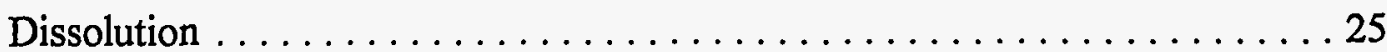

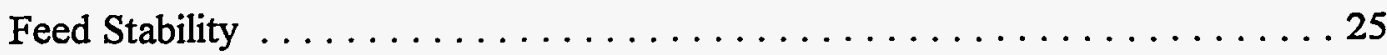

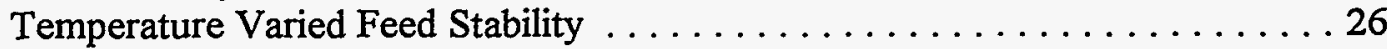

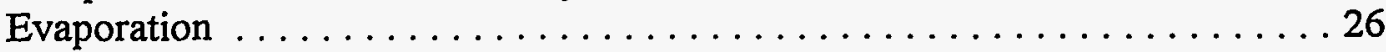

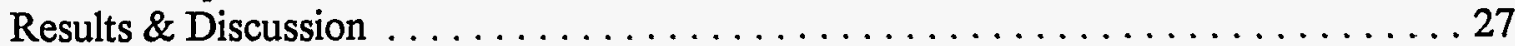

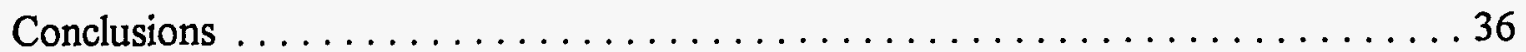

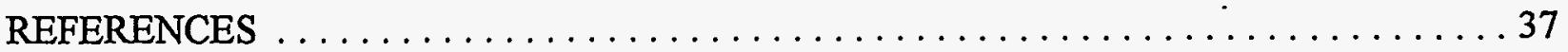


Table 1. Summary of calcine dissolution results of previous researchers $\ldots \ldots \ldots \ldots 4$

Table 2. Sign nomenclature and variable definition used in the statistically designed calcine dissolution experiments $\ldots \ldots \ldots \ldots \ldots \ldots \ldots \ldots \ldots \ldots \ldots$

Table 3. Table of signs indicating the results of the experiments with Runs \#17 and \#20

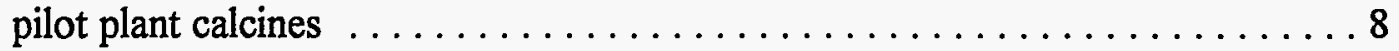

Table 4. Effects and interaction analysis of the statistically designed dissolution

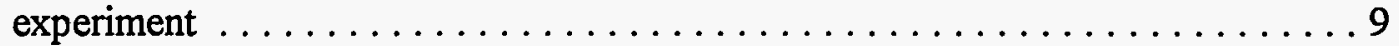

Table 5. Experimental results at limiting conditions for the major calcine types $\ldots \ldots \ldots 12$

Table 6. Results of dissolution studies in varying $\mathrm{HNO}_{3}$ concentrations $\ldots \ldots \ldots \ldots 13$

Table 7. Results of dissolution studies on Run \#74 ( $\mathrm{Zr}$ ) pilot plant calcine in the presence

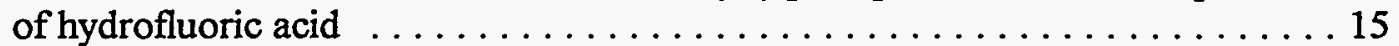

Table 8. Chemical analysis of dissolved Run \#20 pilot plant calcine and the UDS $\ldots \ldots 16$

Table 9. Chemical analysis of dissolved Run \#74 pilot plant calcine and the UDS . . . . 17

Table 10. Chemical analysis of dissolved Run \#17 pilot plant calcine and the UDS ...

Table 11. Chemical analysis of dissolved Runs \#64 \& \#1027 pilot plant calcines

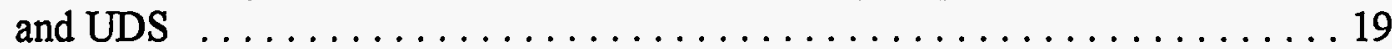

Table 12. Solubility product estimation for calcium sulfate in calcine dissolution liquid . . 28 


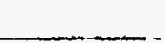




\section{LIST OF FIGURES}

Figure 1. Two way table for evaluation of two factor (AR) interactions for the statistical

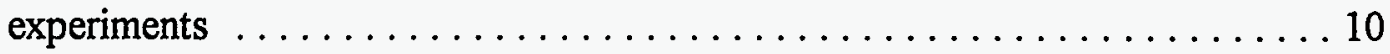

Figure 2. Precipitate concentration found in solutions of Run \#74 dissolved in $5 \underline{\mathrm{M}}$ acid . 27

Figure 3. Calcium ion prediction based on elemental composition and percent dissolution for Run $\# 74$ dissolution liquid . . . . . . . . . . . . . . . . . . . 29

Figure 4. Elemental sulfur ion prediction based on elemental composition and percent dissolution for Run $\# 74$ dissolution liquid $\ldots \ldots \ldots \ldots \ldots \ldots \ldots \ldots \ldots$

Figure 5. Solubility quotients for Run $\# 74$ calcine dissolved in $5 \underline{\mathrm{M}}$ acid $\ldots \ldots \ldots \ldots 31$

Figure 6. Predicted feed stability of dissolver solutions. Calcines dissolved in $10 \mathrm{~mL}$ of $5 \underline{\mathrm{M}}$ nitric acid per gram of calcine for 30 minutes at temperatures of $90-100^{\circ} \mathrm{C}$

Figure 7. Temperature dependence of $\mathrm{CaSO}_{4}$ solubility. Data gathered from Run \#74 calcine dissolved at $10 \mathrm{~mL} 2 \underline{\mathrm{M}}$ nitric acid per gram calcine, $90-100^{\circ} \mathrm{C}$, and 30

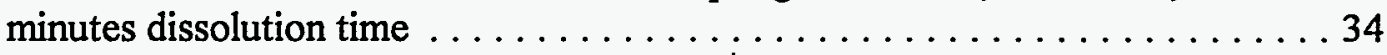

Figure 8. Effect of evaporation on feed stability. Experiments performed on Run \#17 calcine dissolved in $8 \underline{\mathrm{M}}$ nitric acid, $10 \mathrm{~mL}$ acid per gram calcine, 30 minute

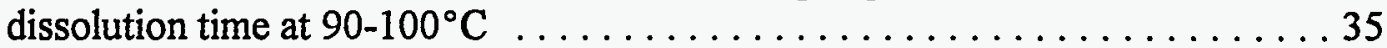




\section{INTRODUCTION}

The Idaho Chemical Processing Plant (ICPP) formerly reprocessed irradiated nuclear fuels for recovery of fissionable uranium. Radioactive liquid wastes resulting primarily from reprocessing activities are solidified to a mixture of predominately oxides in a fluidized bed calciner. The resulting granular solid is stored in near-surface concrete encased stainless steel bins at the ICPP. Since the only material recovered from reprocessing efforts was uranium, the activation products, i.e., the transuranics and lanthanides, as well as fission products such as cesium and strontium, remained in the liquid waste and were ultimately solidified in the calcine. Fuels were entirely dissolved (both the fuel material and cladding) during headend reprocessing. Consequently, the bulk of solid calcine is comprised of inert or matrix materials ( $\approx 99 \mathrm{wt} . \%)$ with the balance constituting the radioactive components.

Current plans for the long term, final storage of ICPP calcines involve immobilization in a glass or glass-ceramic waste form prior to permanent disposal. Technologies are currently being examined to minimize the amount of material which must be immobilized and sent to a repository. Ongoing efforts to identify alternative calcine processing methods include separation of radionuclides from acidic aqueous solutions. Consequently, the dissolution of solid calcine is a prerequisite for any aqueous treatment or separation scheme. Furthermore, the stability of the dissolved calcine solutions (with regard to solids formation) is an important parameter with regards to downstream separation unit operations.

Initial scoping studies with non-radioactive pilot plant calcines have been completed to examine the following:

- Effectiveness of acid dissolution (using both dilute $\mathrm{HNO}_{3}$ and $\mathrm{HNO}_{3}-\mathrm{HF}$ solutions) of various calcines.

- Composition characterization of the resulting dissolver solutions and undissolved solids (UDS).

- Stability of the acidic dissolver solutions with regards to solids formation.

This report is divided into two sections; the first dealing with dissolution of pilot plant calcines, while the second section addresses the stability of the resulting acidic solution from pilot plant calcine dissolution. 


\section{BACKGROUND}

Previous researchers have examined the solubility of simulated and actual ICPP calcines in acidic media. Studies of this type were primarily intended to address bed dissolution in the New Waste Calciner Facility (NWCF), where the liquid waste solutions are solidified to calcine. Some of these results are presented in Table 1. As indicated, previous calcine dissolution studies have focussed on nitric acid as the dissolvent media of choice. Important parameters of dissolution are the acid concentration, dissolution time and temperature, as well as the ratio of acid volume to calcine mass. These were the primary variables studied in this work, and the measured effect was the weight percent of calcine which actually dissolved. A statistical experimental design was used to evaluate the effect of the individual variables on the measured response. The design and methodology of the dissolution experiments were based predominately on the results of previous researchers and conducted to extend the body of knowledge associated with the dissolution of various calcine types. Although not studied in detail, mixing of the solid/ liquid slurry during dissolution is expected to play a significant role in the dissolution process. Sufficient mixing must be provided to insure that reaction kinetics, as opposed to diffusion, is the rate limiting step in the dissolution mechanism.

Following calcine dissolution, subsequent processing options will likely require a clarified feed solution. It is therefore imperative that the resulting acidic feed solutions from the calcine dissolution process be stable with respect to the precipitation of dissolved components. Literature sources indicating attempts to characterize the stability of the acidic solutions resulting from calcine dissolutions were not found. 
Table 1. Summary of calcine dissolution results of previous researchers.

\begin{tabular}{|c|c|c|c|}
\hline $\begin{array}{c}\text { Calcine } \\
\text { Type }\end{array}$ & $\begin{array}{c}\text { Wt. \% } \\
\text { Dissolved } \\
\end{array}$ & $\begin{array}{l}\text { Dissolution } \\
\text { Conditions } \\
\end{array}$ & Ref. \\
\hline \multirow{2}{*}{$\begin{array}{l}\text { "Hot" } \\
\mathrm{Zr} / \mathrm{Na} \\
(5: 1)\end{array}$} & $77 \%$ & $\begin{array}{l}\text { Acid } / \text { Calcine Ratio }=15 \mathrm{~mL} / 0.95 \mathrm{~g} \\
\text { Temp. }=90^{\circ} \mathrm{C} \quad \text { Time }=9 \text { days } \\
\text { Acid Conc. }=5 \mathrm{M} \mathrm{HNO}_{3}\end{array}$ & [1] \\
\hline & $>99.9 \%$ & $\begin{array}{l}\text { Acid } / \text { Calcine Ratio }=150 \mathrm{~mL} / 1.93 \mathrm{~g} \\
\text { Temp. }=\approx 90^{\circ} \mathrm{C} \quad \text { Time }=\text { Uncertain } \\
\text { Acid Conc. }=8 \mathrm{M} \mathrm{HNO} 3\end{array}$ & [1] \\
\hline \multirow{2}{*}{$\begin{array}{l}\text { "Hot" } \\
\mathrm{Al} \\
\text { (WCF) }\end{array}$} & $>99 \%$ & $\begin{array}{l}\text { Acid } / \text { Calcine Ratio }=\text { Uncertain } \\
\text { Temp. }=25^{\circ} \mathrm{C} \text { Time }=1000 \text { hours } \\
\text { Acid Conc. }=0.5 \underline{\mathrm{M} \mathrm{HNO}_{3}}\end{array}$ & [2] \\
\hline & 93\% & $\begin{array}{l}\text { Acid } / \text { Calcine Ratio }=10 \mathrm{~mL} / 1 \mathrm{~g} \\
\text { Temp. }=90^{\circ} \mathrm{C} \text { Time }=30 \text { minutes } \\
\text { Acid Conc. }=8 \mathrm{M} \mathrm{HNO}_{3}\end{array}$ & [7] \\
\hline $\begin{array}{c}\text { Pilot } \\
\text { Plant } \\
\text { Al }\end{array}$ & $80 \%$ & $\begin{array}{l}\text { Acid/Calcine Ratio }=\text { Uncertain } \\
\text { Temp. }=50^{\circ} \mathrm{C} \quad \text { Time }=24 \text { hours } \\
\text { Acid Conc. }=10 \mathrm{MHNO}_{3} \quad \text { No Mixing }\end{array}$ & [3] \\
\hline \multirow{3}{*}{$\begin{array}{l}\text { Pilot } \\
\text { Plant } \\
\text { Zr }\end{array}$} & $71.6 \%$ & $\begin{array}{l}\text { Acid } / \text { Calcine Ratio }=1 \mathrm{~L} / 200 \mathrm{~g} \\
\text { Temp. }=70^{\circ} \mathrm{C} \text { Time }=30 \text { minutes } \\
\text { Acid Conc. }=8 \mathrm{M} \mathrm{HNO}_{3}\end{array}$ & \multirow[t]{2}{*}{ [4] } \\
\hline & $82.9 \%$ & $\begin{array}{l}\text { Acid } / \text { Calcine Ratio }=1 \mathrm{~L} / 200 \mathrm{~g} \\
\text { Temp. }=90^{\circ} \mathrm{C} \text { Time }=30 \text { minutes } \\
\text { Acid Conc. }=10 \mathrm{MNO}_{3}\end{array}$ & \\
\hline & $86-87 \%$ & $\begin{array}{l}\text { Acid } / \text { Calcine Ratio }=1 \mathrm{~L} / 100 \mathrm{~g} \\
\text { Temp. }=90^{\circ} \mathrm{C} \text { Time }=30 \text { minutes } \\
\text { Acid Conc. }=8 \underline{\mathrm{M} \mathrm{HNO}} \mathrm{HNO}_{3}\end{array}$ & \multirow[t]{2}{*}{ [5] } \\
\hline \multirow{2}{*}{$\begin{array}{c}\text { "Hot" } \\
\mathrm{Zr}\end{array}$} & $96.6 \%$ & $\begin{array}{l}\text { Acid } / \text { Calcine Ratio }=1 \mathrm{~L} / 100 \mathrm{~g} \\
\text { Temp. }=90^{\circ} \mathrm{C} \quad \text { Time }=30 \text { minutes } \\
\text { Acid Conc. }=8 \mathrm{M} \mathrm{HNO}_{3}\end{array}$ & \\
\hline & -95\% & $\begin{array}{l}\text { Acid } / \text { Calcine Ratio }=10 \mathrm{~mL} / 1 \mathrm{~g} \\
\text { Temp. }=90^{\circ} \mathrm{C} \quad \text { Time }=30 \text { minutes } \\
\text { Acid Conc. }=8 \mathrm{M} \mathrm{HNO}_{3}\end{array}$ & [7] \\
\hline
\end{tabular}

${ }^{\dagger}$ Mixing of the solid/liquid slurry was provided in all other experiments. 


\section{PART I: PILOT PLANT CALCINE DISSOLUTION STUDIES}

\section{Purpose \& Scope}

The experimental scope centered predominantly on evaluating the importance of temperature, nitric acid concentration, ratio of acid volume to calcine mass, and time on the amount (as a weight percentage) of calcine dissolved. These effects were studied for several representative pilot plant calcine types:

- Run \#74 Zirconia calcine

- Run \#17 Zirconia/Sodium calcine (3.5:1)

- Run \#64 Zirconia/Sodium calcine (5:1)

- Run \#1027 Alumina calcine

- Run \#20 Alumina/Zirconia/Sodium calcine (7:3:1.25)

Two statistically designed experiments with Run \#17 (Zr/Na) and Run \#20 (Al/Zr/Na) calcines were conducted to rank the importance of the four process variables on the dissolution process. The Run \#17 calcine was selected as a reasonable surrogate for all of the $\mathrm{Zr}$ and $\mathrm{Zr} / \mathrm{Na}$ blend calcines. The Run \#20 "three way blend" was selected since an Al calcine was unavailable which did not contain large amounts of $\alpha$ - or $\gamma$-Al, which are typically insoluble in acidic media. These results appear to be representative for the other major calcine types, and a "universal" dissolution recipe was proposed and tested.

In addition, the composition of the acidic solutions and undissolved solids (UDS) from Runs \#74 and \#20 pilot plant calcines were characterized by chemical analysis. Finally, the effect of varying the hydrofluoric acid concentration in nitric acid dissolution media on the amount of Run \#74 calcine dissolved was examined. 


\section{Experimental Procedure}

The experimental procedure for determining the weight percentage of pilot plant calcine dissolved is outlined below.

(1) One gram calcine samples were weighed into beakers. A 60:40 wt.\% mixture of product to fines (approximately $0.6 \mathrm{~g}$ product and $0.4 \mathrm{~g}$ fines) was used in all experiments.

(2) The appropriate amount of the proper concentration acid was added to the sample. The sample was then placed on a hot plate/stirrer and rapidly agitated (with a magnetic stir bar) for the required length of time. In the case of elevated dissolution temperatures, the acid was preheated before addition to the solid calcine sample. The hot plate was used to maintain elevated temperatures during the dissolution.

(3) After the appropriate length of dissolution time, the slurry was immediately gravity filtered through Whatman 542 ashless filter paper. The liquid filtrate was set aside for subsequent testing and analysis. The solids were washed with distilled water to completely remove residual nitric acid. The liquid filtrate from solids washing was discarded.

(4) The filter paper containing undissolved solids was ashed at $600^{\circ} \mathrm{C}$ in a pre-weighed ceramic crucible for one hour. Thus, the weight of undissolved solids was determined and the wt. \% calcine dissolved calculated from this information and the initial sample weight.

(5) For those samples that the UDS were to be submitted for characterization (by XRD analysis), a fourth replicate was dissolved and treated in accord with steps (1) - (3) above. However, this sample was not ashed in accord with step (4) to alleviate solids oxidation to a different chemical form.

Each experiment was performed at the different conditions with triplicate samples. These replicates were averaged and the standard deviation calculated. If large variances were observed in the triplicate results, that experiment was generally repeated. 


\section{Results \& Discussion}

Statistically Designed Dissolution Experiments

Two statistically designed experiments were conducted to establish the main effects and interactions of the following four process variables on the weight percent of calcine dissolved:

- Nitric Acid Concentration (A)

- Temperature (D)

- Acid/Calcine Ratio (R)

- Time (T)

These statistical experiments were designed and conducted in accord with Box et. al. [6] and were simple $2^{n}$ factorial designs. Since the effects of four variables $(A, D, R$, and $T$ ) were measured for a single response (wt. \% calcine dissolved), $n=4$ and $2^{n}=2^{4}=16$ experimental data points were required to establish the main effects and interactions. Experiments of this design were conducted for both Run $\# 17(\mathrm{Zr} / \mathrm{Na})$ and Run $\# 20(\mathrm{Al} / \mathrm{Zr} / \mathrm{Na})$ calcines. In accord with Box [6], standard "sign" nomenclature was used to define variable ranges and are listed in Table 2. The variables and ranges were selected based on the results of previous researchers as listed in Table 1. The values chosen for the studied variables were intended to represent limiting conditions of calcine dissolution.

Table 2. Sign nomenclature and variable definition used in the statistically designed calcine dissolution experiments.

\begin{tabular}{|c|c|c|c|c|c|}
\hline \multirow[b]{2}{*}{ Calcine } & \multirow[b]{2}{*}{ Sign } & \multicolumn{4}{|c|}{ Experimental Conditions } \\
\hline & & $\begin{array}{c}\text { Acid/Calcine } \\
\text { Ratio (R) } \\
\end{array}$ & $\begin{array}{l}\text { Time } \\
(\mathrm{T})\end{array}$ & $\begin{array}{l}\text { Acid Conc. } \\
\text { (A) }\end{array}$ & $\begin{array}{l}\text { Temp. } \\
\text { (D) }\end{array}$ \\
\hline \multirow{2}{*}{$\begin{array}{c}\text { Run \#17 } \\
\mathrm{Zr} / \mathrm{Na} \\
(3.7: 1) \\
\end{array}$} & + & $100 \mathrm{~mL} / 1 \mathrm{~g}$ & 4 hours & $8 \underline{\mathrm{M} \mathrm{HNO}_{3}}$ & $90^{\circ} \mathrm{C}$ \\
\hline & - & $5 \mathrm{~mL} / 1 \mathrm{~g}$ & $30 \mathrm{~min}$ & $2 \mathrm{M} \mathrm{HNO}_{3}$ & $25^{\circ} \mathrm{C}$ \\
\hline \multirow{2}{*}{$\begin{array}{c}\text { Run \#20 } \\
\mathrm{A} 1 / \mathrm{Zr} / \mathrm{Na} \\
(7: 3: 1.25)\end{array}$} & + & $50 \mathrm{~mL} / 1 \mathrm{~g}$ & 2 hours & $8 \underline{\mathrm{M}} \mathrm{HNO}_{3}$ & $90-100^{\circ} \mathrm{C}$ \\
\hline & - & $5 \mathrm{~mL} / 1 \mathrm{~g}$ & $30 \mathrm{~min}$ & $2 \mathrm{M} \mathrm{HNO}_{3}$ & $25^{\circ} \mathrm{C}$ \\
\hline
\end{tabular}


The response measured at each set of experimental conditions was the weight percent of the sample which dissolved. The results are presented in Table 3 with the associated sign nomenclature. Each individual observation was run in triplicate and the standard deviations (67\% confidence interval) represent the sample variance between observations. As anticipated for both calcine types, the least dissolution occurred with all variables at the minimum values (observation \#1) while the greatest amount of dissolution was observed with all variables at the respective maximum values (observation \#16).

Table 3. Table of signs indicating the results of the experiments with Runs \#17 and \#20 pilot plant calcines.

\begin{tabular}{|c|c|c|c|c|c|c|}
\hline \multirow[b]{2}{*}{ Obs. \# } & \multicolumn{4}{|c|}{ Variable } & \multicolumn{2}{|c|}{$\begin{array}{c}\text { Response } \\
\text { (wt. \% dissolved) }\end{array}$} \\
\hline & $\begin{array}{c}\text { Acid/ } \\
\text { Calc. } \\
\mathbf{R} \\
\end{array}$ & $\begin{array}{c}\text { Time } \\
\mathrm{T}\end{array}$ & $\begin{array}{c}\text { Acid } \\
\text { Conc. } \\
\text { A } \\
\end{array}$ & $\begin{array}{c}\text { Temp. } \\
\text { D }\end{array}$ & $\begin{array}{l}\text { Run \#17 } \\
(\mathrm{Zr} / \mathrm{Na}) \\
\end{array}$ & $\begin{array}{l}\text { Run \#20 } \\
(\mathrm{Al} / \mathrm{Na})\end{array}$ \\
\hline 1 & - & - & - & - & $48.72 \pm 1.92$ & $38.84 \pm 0.48$ \\
\hline 2 & + & - & - & - & $74.61 \pm 1.41$ & $65.40 \pm 0.38$ \\
\hline 3 & - & + & - & - & $49.73 \pm 2.12$ & $41.21 \pm 1.76$ \\
\hline 4 & + & + & - & - & $90.24 \pm 0.43$ & $71.74 \pm 0.41$ \\
\hline 5 & - & - & + & - & $57.91 \pm 1.04$ & $56.44 \pm 5.78$ \\
\hline 6 & + & - & + & - & $88.04 \pm 2.34$ & $74.21 \pm 0.13$ \\
\hline 7 & - & + & + & - & $64.71 \pm 2.73$ & $59.99 \pm 1.14$ \\
\hline 8 & + & + & + & - & $97.79 \pm 0.47$ & $81.66 \pm 0.87$ \\
\hline 9 & - & - & - & + & $56.65 \pm 1.48$ & $49.58 \pm 2.92$ \\
\hline 10 & + & - & - & + & $99.50 \pm 0.04$ & $88.31 \pm 0.58$ \\
\hline 11 & - & + & - & + & $82.15 \pm 2.73$ & $49.09 \pm 2.67$ \\
\hline 12 & + & + & - & + & $99.61 \pm 0.04$ & $92.09 \pm 0.47$ \\
\hline 13 & - & - & + & + & $89.74 \pm 1.32$ & $89.94 \pm 0.76$ \\
\hline 14 & + & - & + & + & $99.56 \pm 0.18$ & $90.93 \pm 2.57$ \\
\hline 15 & - & + & + & + & $91.41 \pm 0.28$ & $88.53 \pm 0.28$ \\
\hline 16 & + & + & + & + & $99.77 \pm 0.09$ & $96.59 \pm 0.10$ \\
\hline
\end{tabular}


The fundamental purpose of performing a statistically designed experiment is to establish or rank the effects and interactions of process variables on a measured response, in this case weight percent calcine dissolved. An effect/interaction analysis was performed for the individual calcine types utilizing Yates Algorithm in accord with Box [6]. Results of this analysis are presented in Table 4.

Table 4. Effects and interaction analysis of the statistically designed dissolution experiment.

\begin{tabular}{|c|c|c|c|}
\hline \multirow[b]{2}{*}{ Variable } & \multicolumn{2}{|c|}{ Effect on Wt. \% Dissolved } & \multirow{2}{*}{$\begin{array}{c}\text { Effect/ } \\
\text { Interaction }\end{array}$} \\
\hline & $\begin{array}{c}\text { Run \#17 } \\
(\mathrm{Zr} / \mathrm{Na})\end{array}$ & $\begin{array}{l}\text { Run \#20 } \\
(\mathrm{Al} / \mathrm{Na})\end{array}$ & \\
\hline $\begin{array}{l}\text { Overall } \\
\text { Average }\end{array}$ & $+80.63 \pm 0.43$ & $+70.91 \pm 0.57$ & Average \\
\hline $\mathbf{R}$ & $+26.01 \pm 0.43$ & $+23.41 \pm 0.57$ & \multirow{4}{*}{$\begin{array}{c}\text { Main } \\
\text { Effects }\end{array}$} \\
\hline $\mathrm{D}$ & $+18.33 \pm 0.43$ & $+19.45 \pm 0.57$ & \\
\hline A & $+10.97 \pm 0.43$ & $+17.75 \pm 0.57$ & \\
\hline $\mathrm{T}$ & $+7.585 \pm 0.43$ & $+3.406 \pm 0.57$ & \\
\hline AR & $-5.665 \pm 0.43$ & $-11.29 \pm 0.57$ & \multirow{6}{*}{$\begin{array}{c}\text { Two } \\
\text { Factor } \\
\text { Interactions }\end{array}$} \\
\hline $\mathrm{AD}$ & $-0.323 \pm 0.43$ & $+3.976 \pm 0.57$ & \\
\hline TR & $-1.160 \pm 0.43$ & $+2.401 \pm 0.57$ & \\
\hline TD & $-0.713 \pm 0.43$ & $-1.521 \pm 0.57$ & \\
\hline DR & $-6.390 \pm 0.43$ & $-0.719 \pm 0.57$ & \\
\hline $\mathrm{AT}$ & $-2.978 \pm 0.43$ & $+0.406 \pm 0.57$ & \\
\hline $\mathrm{ADR}$ & $-4.868 \pm 0.43$ & $-6.879 \pm 0.57$ & \multirow{4}{*}{$\begin{array}{c}\text { Three } \\
\text { Factor } \\
\text { Interactions }\end{array}$} \\
\hline TDR & $-5.553 \pm 0.43$ & $+0.434 \pm 0.57$ & \\
\hline ATR & $+1.533 \pm 0.43$ & $+0.341 \pm 0.57$ & \\
\hline ATD & $-2.955 \pm 0.43$ & $-0.166 \pm 0.57$ & \\
\hline ATDR & $+4.450 \pm 0.43$ & $+0.359 \pm 0.57$ & $\begin{array}{l}\text { Four Factor } \\
\text { Interaction }\end{array}$ \\
\hline
\end{tabular}


The overall average in Table 4 is the average amount dissolved in all sixteen experiments with a given calcine type. The main effects $(R, D, A, T)$ are a measure of the average impact the variables independently have on the dissolution process. For example, with Run \#17 calcine a change in the acid/calcine ratio, $\mathrm{R}$, from $5 \mathrm{~mL} / 1 \mathrm{~g}(-)$ to $100 \mathrm{~mL} / 1 \mathrm{~g}(+)$ will have an average effect of increasing the amount of calcine dissolved by $+26.01 \pm 0.43 \mathrm{wt}$. $\%$. The acid/calcine ratio has the most significant impact on the measured response for both types of calcine. In fact, the importance of the four variables on amount of calcine dissolved decreases in the order:

$$
\text { Acid/Calc. Ratio (R) }>\text { Temp.(D) }>\mathrm{HNO}_{3} \text { Conc. (A) }>\text { Diss. Time (T) }
$$

As a consequence of "ranking" effect importance, the dissolution time, $\mathrm{T}$, has the least effect on the dissolution process.

The second, third, and fourth order effects provide an indication of multiple variable effects on the measured response. It is assumed that the third and fourth order effects are negligible and result from experimental noise. The experimental data indicate that the effect of $\mathrm{R}$ is more pronounced at the upper level of acid concentration, $\mathrm{A}$. Conversely, the effects of $\mathrm{A}$ are more pronounced at larger values of $R$. The large $A R$ interaction is an indication that $A$ and $\mathrm{R}$ do not behave additively, and therefore interact. A measure of this interaction is supplied by the difference between the average effect of $R$ at both the lower and upper limits of $A$. By convention, half of this difference is the AxR (or simply AR) interaction. Due to the large AR interaction, it may be inappropriate to consider the effects of $A$ and $R$ independently. This interaction is anticipated with the realization that specification of acid concentration and the acid to calcine ratio is redundant in that these two variables taken together specify the moles of acid added to the dissolver. However, note that the acid to calcine ratio must be kept sufficient to insure solubility limits are not exceeded, resulting in precipitation of dissolved species, i.e. an unstable feed for subsequent separations processes.

It is easiest to interpret the two factor interactions with the two-way tables shown in Figure 1. The corner numbers represent the average of four measurements taken at the respective signs of $A$ and $R$. The numbers in parenthesis indicate the difference between these averages. For Run \#17 calcine, the AR interaction is given by:

$$
\mathrm{AR}=(5.30-16.63) / 2=(20.35-31.68) / 2=-5.665
$$

For the statistical experiments with Run \#17 calcine, the AR interaction occurs statistically since one of the experimental conditions, $R$, was tested near the limiting response of $100 \%$ dissolution. This apparently creates an anomaly in the data which is reflected in the statistics. For this reason, the AR interaction is probably not as important for the Run \#17 calcine, and a change in A from $2 \mathrm{M}$ to $8 \mathrm{M} \mathrm{HNO}_{3}$ is considered to increase dissolution by approximately $11 \%$ under all conditions. 
Figure 1. Two way table for evaluation of two factor (AR) interactions for the statistical experiments.

Run \#17

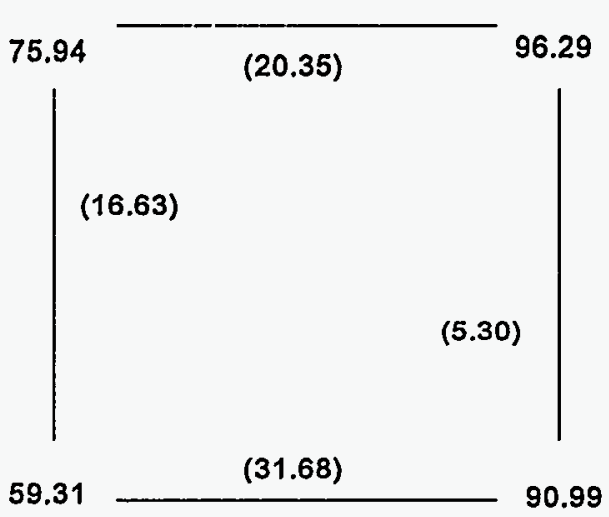

(+) $8 \mathrm{M}$

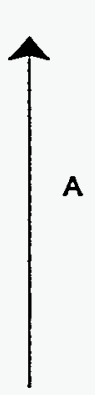

$(-) 2 M$
Run $\$ 20$

73.73

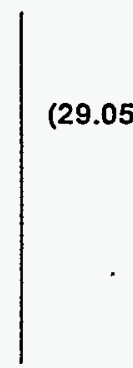

(12.12)

8.85

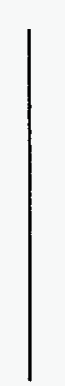

(34.71)

44.68

$5 \mathrm{ml} / \mathrm{g}$

$100 \mathrm{ml} / \mathrm{g}$

$5 \mathrm{mlg}$

$50 \mathrm{ml} / \mathrm{g}$

$\mathbf{R}$

In the case of experiments with the Run $\# 20$ calcine, large $R$ produces a substantial increase in the amount of dissolution. The AR interaction occurs because at low $R$, an increase in A dramatically increases the amount of calcine dissolved. By contrast, increasing $A$ at higher $\mathrm{R}$ has a much smaller effect on the dissolution. Thus, the AR interaction for Run \#20 calcine has a rather large effect on the amount dissolved. It may be impractical to consider these effects independently due to the large interaction. However, the magnitude of the AR interaction. is substantially less than either of the individual effects. Therefore, it is assumed that consideration of only the main effects is justified.

A full set of statistically designed experiments were conducted only for Run \#17 and Run \#20 calcines. The major variables affecting the amount dissolved were found to be the acid/calcine ratio, temperature and nitric acid concentration. It was desirable to evaluate the importance of these process variables on other important pilot plant calcine types without the labor intensive process of performing the full gamut of experiments. The remaining calcine types (Runs \#64, \#74, and \#1027) were therefore tested at limiting conditions of the four process variables and the amount dissolved was determined. The results of these tests at the respective conditions are shown in Table 5. Also shown in Table 5 are the results of the Run \#17 and \#20 calcines (from the statistical tests) for comparison. 
Table 5. Experimental results at limiting conditions for the major calcine types.

\begin{tabular}{||c|c|c||}
\hline \multirow{2}{*}{$\begin{array}{c}\text { Constant Variables: } \\
\text { Call Experiments) }\end{array}$} & \multicolumn{2}{c||}{$\begin{array}{c}\text { Dissolution Time }=30 \text { minutes } \\
\text { Acid/Calcine Ratio }=5 \mathrm{~mL} \text { acid } / 1 \mathrm{~g} \text { calcine } \\
\text { Dissolution Temp. }=90-100^{\circ} \mathrm{C}\end{array}$} \\
\cline { 2 - 4 } & \multicolumn{2}{|c|}{$\begin{array}{c}\text { Wt. \% Dissolved for the Indicated } \\
\text { Nitric Acid Concentration }\end{array}$} \\
\hline Run \#17 (Zr/Na 3.5:1) & $2 \mathrm{M} \mathrm{HNO}_{3}$ & $8 \mathrm{M} \mathrm{HNO}_{3}$ \\
\hline Run \#20 (Av/Zr/Na 7:3:1.25) & $56.65 \pm 1.48$ & $89.74 \pm 1.32$ \\
\hline Run \#64 (Zr/Na 5:1) & $49.58 \pm 2.92$ & $89.94 \pm 0.76$ \\
\hline Run \#74 (Zr) & $55.85 \pm 1.83$ & $89.65 \pm 0.28$ \\
\hline Run \#1027 (Al) & $45.60 \pm 1.85$ & $85.15 \pm 5.74$ \\
\hline
\end{tabular}

As indicated in Table 5, all dissolution variables except nitric acid concentration were held constant in this set of experiments. The constant variables ( $T, R, D)$ were maintained at the limiting values identical to those used in the statistical experiments. Only the nitric acid concentration was varied, again between limits identical to those used in the statistical experiments. Note that for all calcines examined, with the exception of Run \#1027 (Al), the amount dissolved is reasonably constant for a given set of experimental conditions. As a consequence of this observation, it was concluded that each studied process variable impacts the dissolution in precisely the same manner, regardless of the particular calcine type. For example, the acid/calcine ratio has the greatest effect on the amount of each calcine type dissolved; conversely, dissolution time has the least effect, regardless of calcine type. The notable exception to the trend indicated in Table 5 is Run \#1027 alumina calcine. Analytical results ( $\mathrm{x}$-ray diffraction) indicate this particular calcine is comprised mainly of $\gamma$-alumina which is largely insoluble in acidic media. The presence of $\gamma-\mathrm{Al}$ in Run \#1027 calcine accounts for the greatly reduced amount of material dissolved in acidic solution.

Finally, experiments with each major type of pilot plant calcine were performed to evaluate process parameters applicable to large scale dissolution. The statistical experiments indicate dissolution time has little effect on the amount of calcine dissolved. For a continuous process, short residence times are desirable; consequently, dissolution times of 30 minutes would be feasible in a large scale dissolution process. For this reason, the dissolution time was held constant at $\mathrm{T}=30$ minutes in this set of experiments. Temperature was shown to have a dramatic effect on the amount of pilot plant calcines dissolved. Elevated temperatures, near the boiling point, would be feasible in a large scale dissolution process. Consequently, the temperature was held constant at $90-100^{\circ} \mathrm{C}$. From a waste minimization standpoint, it is 
desirable to utilize the smallest volume of acid per unit weight of solid calcine possible. In conjunction with results of statistically designed experiments, a small increase in the acid/calcine ratio could dramatically decrease the required concentration of nitric acid for $90 \mathrm{wt} \%$ or greater calcine dissolution. Thus, an acid/calcine ratio of $10 \mathrm{~mL}$ acid per 1 gram calcine $(10 \mathrm{~L} / 1 \mathrm{~kg})$ was evaluated for various nitric acid concentrations. The experimental results are summarized for these conditions in Table 6.

Table 6 indicates $5 \mathrm{M}$ nitric acid is sufficient to achieve approximately $90 \mathrm{wt} . \%$ dissolution of the $\mathrm{Zr}$ and $\mathrm{Zr} / \mathrm{Na}$ blend calcines at $10 \mathrm{~mL} / 1 \mathrm{~g}(10 \mathrm{~L} / \mathrm{kg})$. In fact, for Runs \#74 (Zr) and \#17 ( $\mathrm{Zr} / \mathrm{Na}$ 3.5:1) the difference in amount dissolved for $5 \underline{\mathrm{M}}$ and $8 \underline{\mathrm{M}}$ nitric acid is negligible and cannot be distinguished from experimental error. For Runs \#20, \#64, and \#1027, an increase in nitric acid concentration from $5 \underline{M}$ to $8 \underline{\mathrm{M}}$ increased the dissolved amount by only 5 to $7 \mathrm{wt}$. \%. From these results, it was concluded that the following set of conditions are sufficient for approximately $90 \mathrm{wt}$. \% dissolution, independent of the calcine types investigated:

- Maximum nitric acid concentration of $5 \underline{\mathrm{M}}$

- Acid/calcine ratio of $10 \mathrm{~mL}$ acid/1 gram calcine

- Dissolution temperature of $90^{\circ} \mathrm{C}$

- Minimum dissolution time of 30 minutes

These results compare favorably with those of previous researchers as summarized in Table 1.

Table 6. Results of dissolution studies in varying $\mathrm{HNO}_{3}$ concentrations.

\begin{tabular}{||c|c|c|c||}
\hline \multirow{2}{*}{$\begin{array}{c}\text { Constant Variables: } \\
\text { (All Experiments) }\end{array}$} & \multicolumn{2}{c||}{$\begin{array}{l}\text { Dissolution Time }=30 \text { minutes } \\
\text { Acid/Calcine Ratio }=10 \mathrm{~mL} \text { acid } / 1 \mathrm{~g} \text { calcine } \\
\text { Dissolution Temperature }=90-100^{\circ} \mathrm{C}\end{array}$} \\
\hline \multirow{3}{*}{$\begin{array}{c}\text { Wt. \% Dissolved for the Indicated } \\
\text { Nitric Acid Concentration }\end{array}$} \\
\cline { 2 - 5 } & $2 \underline{\mathrm{M}}$ & $5 \underline{\mathrm{M}}$ & $8 \underline{\mathrm{M}}$ \\
\hline Run \#17 (Zr/Na 3.5:1) & $75.14 \pm 1.48$ & $88.00 \pm 2.29$ & $88.59 \pm 1.61$ \\
\hline Run \#20 (Al/Zr/Na 7:3:1.25) & $72.54 \pm 7.41$ & $90.23 \pm 1.13$ & $97.34 \pm 0.31$ \\
\hline Run \#64 (Zr/Na 5:1) & $80.79 \pm 1.64$ & $92.33 \pm 0.27$ & $97.22 \pm 0.23$ \\
\hline Run \#74 (Zr) & $71.47 \pm 2.14$ & $94.86 \pm 1.35$ & $93.95 \pm 0.84$ \\
\hline Run \#1027 (Al) & $51.25 \pm 1.08$ & $51.33 \pm 1.59$ & $57.36 \pm 1.31$ \\
\hline \hline
\end{tabular}


It must be kept in mind that scale-up of the dissolution process or the dissolution of actual radionuclide containing calcines may indicate somewhat different results or challenges than indicated in these studies. The scale-up process may not be as effective when kilogram quantities of calcines are subjected to dissolution. A second, and perhaps more pertinent question, revolves around the behavior of radionuclides in the dissolution process. The behavior of these species during dissolution is extremely important since it is precisely these materials which will determine whether the UDS must be disposed of as HLW or LLW. The behavior of radioisotopes during dissolution experiments with radioactive calcine has been tested in subsequent experiments [13]. Results of the radioactive calcine dissolution studies indicate the UDS will contain sufficient quantities of radionuclides to necessitate disposal as HLW.

However, the radionuclide content in the UDS will have a minimal impact on the weight percent dissolved since such a small fraction of the calcine is attributed to radionuclide mass $(<1 \mathrm{wt} . \%)$.

\section{Effect of HF on Dissolution of $\mathrm{Zr}$ Calcine}

Zirconium dioxide readily dissolves in a mixture of nitric and hydrofluoric acids. Zirconia calcines typically contain relatively large amounts of $\mathrm{ZrO}_{2}$, consequently it is of practical interest to examine the effect of nitric acid containing various quantities of $\mathrm{HF}$ as a dissolvent for $\mathrm{Zr}$ calcines. A single set of experiments was performed on Run \#74 calcine to examine the amount of material dissolved in the presence of HF. In this set of experiments, all parameters were kept constant except the HF concentration in a $5 \mathrm{M} \mathrm{HNO}_{3}$ solution. In accord with the dissolution "recipe" developed from the statistically designed experiments, the parameters were:

- Dissolution Temp. $=90-100^{\circ} \mathrm{C}$

- Dissolution Time $=30$ minutes

- Acid/calcine ratio $=10 \mathrm{~mL} / 1 \mathrm{~g}$

- Nitric acid concentration $=5 \underline{\mathrm{M}} \mathrm{HNO}_{3}$

The nitric acid dissolvent contained no $\mathrm{HF}$ (control sample), $0.3 \underline{\mathrm{M}}, 0.6 \underline{\mathrm{M}}, 1 \mathrm{M}$, or $2 \underline{\mathrm{M}}$ HF. The experiments were run in triplicate in accord with the experimental procedure previously outlined. However, Teflon or Nalgene lab equipment replaced glass due to the deleterious effects of HF on glass. The results of these experiments are summarized in Table 7. The control sample, which contained no HF, compares well with the value of $94.86 \pm 1.35 \mathrm{wt}$. \% dissolved reported in Table 6.

From the data presented in Table 7, it is apparent that the addition of even small quantities of HF to the dissolvent dramatically reduces the amount of calcine dissolved. As the amount of HF is increased, the effect is amplified. These observations are readily explained in terms of the calcium content of high $\mathrm{Zr}$ calcines. 
Table 7. Results of dissolution studies on Run \#74 ( $\mathrm{Zr})$ pilot plant calcine in the presence of hydrofluoric acid.

\begin{tabular}{|c|c|}
\hline $\begin{array}{c}\text { Constant Variables: } \\
\text { (All Experiments) }\end{array}$ & $\begin{array}{l}\text { Dissolution Time }=30 \mathrm{Minutes} \\
\text { Acid/Calcine Ratio }=10 \mathrm{~mL} \text { acid } / \mathrm{g} \text { calcine } \\
\text { Dissolution Temperature }=90-100^{\circ} \mathrm{C} \\
\text { Nitric acid Concentration }=5 \mathrm{M} \mathrm{HNO}_{3}\end{array}$ \\
\hline \hline HF Concentration (M) & \multicolumn{1}{c|}{ Wt. \% Dissolved } \\
\hline 0 (Control) & $91.39 \pm 1.43$ \\
\hline 0.3 & $81.66 \pm 3.86$ \\
\hline 0.6 & $72.27 \pm 6.33$ \\
\hline 1 & $71.91 \pm 1.80$ \\
\hline 2 & $48.83 \pm 2.68$ \\
\hline
\end{tabular}

Calcium nitrate is added to high fluoride feed streams (resulting from $\mathrm{HNO}_{3} / \mathrm{HF}$ acid dissolution of $\mathrm{Zr}$-clad fuels) to complex the fluoride by forming insoluble $\mathrm{CaF}_{2}$, thus inhibiting fluoride volatility in the calcination process. A simplified explanation revolves around the equilibrium between solid and dissolved $\mathrm{CaF}_{2}$ :

$$
\mathrm{CaF}_{2(s)} \Longleftrightarrow \mathrm{Ca}_{(\ell)}^{2+}+2 \mathrm{~F}_{(\ell)}^{-}
$$

Fluoride complexants which are more soluble than $\mathrm{CaF}_{2}$ (i.e., $\mathrm{Al}$ or $\mathrm{Zr}$ ) dissolved from the calcine will shift the equilibrium to the right, allowing $\mathrm{CaF}_{2}$ to dissolve. When fluoride is added to the system (as HF), the equilibrium is shifted to the left such that: 1) either the solid calcium fluoride will not dissolve or 2) calcium fluoride will re-precipitate from solution. In actual calcines, the re-precipitation of $\mathrm{CaF}_{2}$ could result in unwanted "carry-down" of radionuclides. Although a greatly oversimplified explanation, the net result is a reduction in the wt. \% of calcine dissolved due to residual solid $\mathrm{CaF}_{2}$. As the HF concentration is increased, the equilibrium is shifted further to the left and the effects are more pronounced.

As a result of these limited studies, it is apparent the use of $\mathrm{HF}$ in calcine dissolution provides little benefit. Consequently, further studies with HF containing dissolvents were not conducted. 


\section{Characterization of Liquids and Undissolved Solids}

Samples from calcine dissolutions were submitted to Analytical Chemistry for analysis. This information provides valuable insight regarding the solubility of different matrix elements in various nitric acid concentrations. Liquid and undissolved solid (UDS) samples were prepared by using an acid/calcine ratio of $10 \mathrm{~mL} / \mathrm{g}$ calcine, dissolution temperature of $90-100^{\circ} \mathrm{C}$, and dissolution time of 30 minutes for the respective $\mathrm{HNO}_{3}$ concentrations.

Run \#20 pilot plant calcine is a "three-way" blend of $\mathrm{Al} / \mathrm{Zr} / \mathrm{Na}$ feeds and the major constituents of the dissolver solution are $\mathrm{Ca}$ and $\mathrm{F}$, in addition to $\mathrm{Zr}, \mathrm{Al}$, and $\mathrm{Na}$. Analytical results of the liquid and UDS samples from acid dissolution of this calcine type are shown in Table 8. From Table 5, 72-97 wt. \% of this calcine dissolved in the various concentrations of nitric acid. Analysis of the UDS from the dissolution process indicates zirconium oxide $\left(\mathrm{ZrO}_{2}\right)$ and calcium stabilized zirconia $\left(\mathrm{Ca}_{0.15} \mathrm{Zr}_{0.85} \mathrm{O}_{1.85}\right)$ are the predominate residuals in the solid. As the acid concentration of the dissolvent increased, the amount of $\mathrm{Zr}$ and $\mathrm{Ca}$ increased in solution. This trend reflects the enhanced dissolution of the UDS as acid concentration increased in the dissolver solution. Note that $>1.75,2.59$, and 2.35 moles of acid (as $\mathrm{H}^{+}$, which reacts to form $\mathrm{H}_{2} \mathrm{O}$ during dissolution) was consumed per gram of calcine in the $2 \underline{\mathrm{M}}, 5 \underline{\mathrm{M}}$, and $8 \underline{\mathrm{M}}$ acid dissolutions, respectively.

Table 8. Chemical analysis of dissolved Run \#20 pilot plant calcine and the UDS.

\begin{tabular}{|c|c|c|c|c|c|c|}
\hline Dissolvent & \multicolumn{2}{|c|}{$\begin{array}{c}2 \mathrm{M} \mathrm{HNNO}_{3} \\
(\log \# 93-08194) \\
\end{array}$} & \multicolumn{2}{|c|}{$\begin{array}{c}5 \mathrm{M} \mathrm{HNNO}_{3} \\
(\mathrm{LOg} \# 93-08194)\end{array}$} & \multicolumn{2}{|c|}{$\begin{array}{c}\text { 8M HNOO } \\
(\text { Log } \# 93-080512)\end{array}$} \\
\hline Element & $\mu \mathrm{g} / \mathrm{mL}$ & $\underline{M}$ & $\mu \mathrm{g} / \mathrm{mL}$ & $\underline{\mathrm{M}}$ & $\mu \mathrm{g} / \mathrm{mL}$ & $\mathrm{M}$ \\
\hline Acid & NA & $<0.251$ & $\mathrm{NA}$ & 2.406 & $\mathrm{NA}$ & 5.653 \\
\hline $\mathrm{Al}$ & 16200 & 0.600 & 20700 & 0.767 & 22800 & 0.845 \\
\hline $\mathrm{B}$ & 948 & 0.088 & 1040 & 0.096 & 1040 & 0.096 \\
\hline $\mathrm{Ca}$ & 16800 & 0.419 & 17600 & 0.439 & 19200 & 0.479 \\
\hline $\mathrm{F}$ & 12200 & 0.642 & 11800 & 0.621 & $\mathrm{NA}$ & 0.68 \\
\hline $\mathrm{Fe}$ & 12 & $2.2 \mathrm{E}-4$ & 551 & 0.0099 & 563 & 0.010 \\
\hline Nitrate & NA & 2.15 & $\mathrm{NA}$ & 5.45 & NA & 8.57 \\
\hline $\mathrm{K}$ & 750 & 0.0192 & 810 & 0.021 & 750 & 0.019 \\
\hline $\mathrm{Na}$ & 3500 & 0.152 & 3700 & 0.161 & 3600 & 0.157 \\
\hline $\mathrm{Sr}$ & 29.2 & $3.3 E-4$ & 30.8 & $3.5 \mathrm{E}-4$ & 36.1 & $4.1 \mathrm{E}-4$ \\
\hline $\mathrm{Zr}$ & 0.899 & $9.9 \mathrm{E}-6$ & 6060 & 0.066 & 8960 & 0.098 \\
\hline Solids & \multicolumn{2}{|c|}{$\begin{array}{l}\text { Majors: } \mathrm{ZrO}_{2} \\
\text { or Ca } \mathrm{Cr}_{0.15} \mathrm{Zr}_{0.85} \mathrm{O}_{1.85} \\
\text { Minors: } \mathrm{CaF}_{2}\end{array}$} & \multicolumn{2}{|c|}{$\begin{array}{l}\text { Majors: } \mathrm{ZrO}_{2} \\
\text { or Ca } \mathrm{Cr}_{0.15} \mathrm{Zr}_{2.85} \mathrm{O}_{1.85} \\
\text { Minors: U Unidentified }\end{array}$} & \multicolumn{2}{|c|}{$\begin{array}{l}\text { Majors: } \mathrm{ZrO}_{2}, \mathrm{CaO}_{2} \\
\text { or Ca } \mathrm{Zr}_{0.15} \mathrm{Zr}_{0.85} \mathrm{O}_{1.85} \\
\text { Minors: } \alpha-\mathrm{Al}\end{array}$} \\
\hline
\end{tabular}

NA $=$ Not Applicable 
Run \#74 pilot plant calcine is a $\mathrm{Zr}$ calcine type and the primary components in the dissolver liquid are $\mathrm{Zr}, \mathrm{Al}, \mathrm{Ca}$, and $\mathrm{F}$. The nitrate concentrations are predominately from the nitric acid dissolvent, although some residual nitrate is contained in the calcine, typically 1 to $5 \mathrm{wt}$. \%. Approximately 1.4, 1.2, and 1.34 moles of acid were consumed per gram of calcine dissolved for the $2 \underline{\mathrm{M}}, 5 \underline{\mathrm{M}}$, and $8 \underline{\mathrm{M}}$ dissolutions, respectively. From Table 5, roughly 71 to $94 \mathrm{wt}$. \% of this calcine was dissolved depending on the concentration of the acid used in the dissolution.

Analysis of the UDS samples indicate the major components contain $\mathrm{Ca}, \mathrm{Zr}$, and $\mathrm{F}$. Accordingly, as higher $\mathrm{HNO}_{3}$ concentrations are used in the dissolvent, the $\mathrm{Ca}$ and $\mathrm{Zr}$ compositions in the dissolver solution increase. Fluoride analysis for the $8 \mathrm{M} \mathrm{HNO}_{3}$ solution is quite low compared with the 2 and $5 \underline{M}$ solutions. This anomaly is attributed to analytical error. The UDS from the dissolution in $8 \mathrm{M} \mathrm{HNO}_{3}$ is reported to contain calcium sulfate $\left(\mathrm{CaSO}_{4}\right)$ as a major constituent. Sulfate, although not directly determined in these solutions, is apparently a constituent of pilot plant calcines. In the stability studies associated with these solutions from dissolved Run \#74 pilot plant calcine (vide infra), the formation of a precipitate has been observed as a function of time. The precipitation is more pronounced for the feed solutions with lower acidity and has been determined to be calcium sulfate.

Table 9. Chemical analysis of dissolved Run \#74 pilot plant calcine and the UDS.

\begin{tabular}{|c|c|c|c|c|c|c|}
\hline \multirow{2}{*}{$\begin{array}{l}\text { Dissolvent } \\
\text { Element }\end{array}$} & \multicolumn{2}{|c|}{$\begin{array}{c}2 \underline{\mathrm{M}} \mathrm{FNO}_{3} \\
(\mathrm{Log} \# 93-080512)\end{array}$} & \multicolumn{2}{|c|}{$\begin{array}{c}5 \underline{\mathrm{M}} \mathrm{HNO}_{3} \\
(\mathrm{Log} \# 93-08194)\end{array}$} & \multicolumn{2}{|c|}{$\begin{array}{c}8 \underline{\mathrm{M}} \mathrm{HNO}_{3} \\
(\mathrm{Log} \# 93-080512)\end{array}$} \\
\hline & $\mu \mathrm{g} / \mathrm{mL}$ & $\underline{\underline{M}}$ & $\mu \mathrm{g} / \mathrm{mL}$ & $\underline{\mathrm{M}}$ & $\mu \mathrm{g} / \mathrm{mL}$ & $\underline{M}$ \\
\hline Acid & NA & 0.558 & NA & 3.781 & NA & 6.740 \\
\hline $\mathrm{Al}$ & 7800 & 0.289 & 13100 & 0.486 & 11800 & 0.437 \\
\hline B & 643 & 0.059 & 932 & 0.086 & 760 & 0.070 \\
\hline $\mathrm{Ca}$ & 15400 & 0.384 & 31200 & 0.778 & 28100 & 0.701 \\
\hline Cs & 480 & 0.0036 & 660 & 0.0050 & 550 & 0.0041 \\
\hline $\mathrm{F}$ & NA & 1.07 & 23600 & 1.24 & NA & 0.77 \\
\hline $\mathrm{Fe}$ & 520 & 0.0093 & 831 & 0.0149 & 724 & 0.013 \\
\hline Nitrate & $\mathrm{NA}$ & 2.05 & NA & 6.39 & NA & 8.60 \\
\hline $\mathrm{K}$ & 25 & $6.4 \mathrm{E}-4$ & NR & NR & 28 & $7.2 \mathrm{E}-4$ \\
\hline $\mathrm{Na}$ & 330 & 0.014 & 280 & 0.012 & 300 & 0.013 \\
\hline $\mathrm{Sr}$ & 544 & 0.0062 & 344 & 0.0039 & 646 & 0.0074 \\
\hline $\mathrm{Zr}$ & 5490 & 0.060 & 20500 & 0.225 & 18600 & 0.204 \\
\hline Solids & \multicolumn{2}{|c|}{$\begin{array}{l}\text { Majors: } \mathrm{CaF}_{2}, \mathrm{CaO}_{2}, \mathrm{ZrO}_{2} \\
\text { Minors: } \mathrm{ZrO}_{2} \\
\text { or } \mathrm{Ca}_{0,15} \mathrm{Zr}_{0,85} \mathrm{O}_{135}\end{array}$} & \multicolumn{2}{|c|}{$\begin{array}{l}\text { Majors: } \mathrm{CaF}_{2}, \mathrm{ZrO}_{2} \\
\text { or Ca } \mathrm{a}_{0.15} \mathrm{Zr}_{0.85} \mathrm{O}_{1.85} \\
\text { Minors: Unidentified }\end{array}$} & \multicolumn{2}{|c|}{$\begin{array}{l}\text { Majors: } \mathrm{CaSO}_{4} \\
\text { Minors: } \mathrm{Na}_{2} \mathrm{SO}_{4}, \mathrm{Na}_{2} \mathrm{Si}_{2} \mathrm{O}_{5}, \\
\quad \mathrm{Na}_{5} \mathrm{Cr}_{3} \mathrm{~F}_{14} \text { or } \mathrm{Ca}_{0.18} \mathrm{Zr}_{0.85} \mathrm{O}_{4}\end{array}$} \\
\hline
\end{tabular}


Run \#17 pilot plant calcine is a $\mathrm{Zr} / \mathrm{Na}$ blend. The analytical results are indicated in Table 10 for the dissolver solution and UDS samples. Table 5 indicates that roughly $75-89 \mathrm{wt}$. \% of this calcine was dissolved in the different nitric acid solutions. Note that 1.2 to 2.1 moles of acid are consumed per gram of calcine dissolved, with the greatest acid consumption at the higher nitric acid concentrations. The UDS samples indicate the predominate residue is calcium fluoride and calcium stabilized zirconia. As the acid concentration of the dissolvent is increased, more calcium, fluoride and zirconium are dissolved. Consequently the concentration of these materials increases in the dissolver solution as the acidity of the dissolvent is increased.

Table 10. Chemical analysis of dissolved Run \#17 pilot plant calcine and the UDS.

\begin{tabular}{|c|c|c|c|c|c|c|}
\hline Dissolvent & \multicolumn{2}{|c|}{$\begin{array}{c}2 \underline{\mathrm{M}} \mathrm{HNO}_{3} \\
(\mathrm{Log} \# 93-080512)\end{array}$} & \multicolumn{2}{|c|}{$\begin{array}{c}5 \underline{\mathrm{M}} \mathrm{HNO}_{3} \\
(\mathrm{Log} \# 93-080512) \\
\end{array}$} & \multicolumn{2}{|c|}{$\begin{array}{c}8 \underline{\mathrm{M}} \mathrm{HNO}_{3} \\
\text { (Log\#93-080512) }\end{array}$} \\
\hline Element & $\mu \mathrm{g} / \mathrm{mL}$ & $\underline{\underline{M}}$ & $\mu \mathrm{g} / \mathrm{mL}$ & $\underline{\mathrm{M}}$ & $\mu \mathrm{g} / \mathrm{mL}$ & $\underline{\mathrm{M}}$ \\
\hline Acid & $\mathrm{NA}$ & 0.776 & NA & 3.149 & NA & 5.911 \\
\hline $\mathrm{Al}$ & 4680 & 0.173 & 5000 & 0.185 & 5150 & 0.191 \\
\hline B & 623 & 0.058 & 642 & 0.059 & 634 & 0.059 \\
\hline $\mathrm{Ca}$ & 14000 & 0.349 & 17700 & 0.442 & 17800 & 0.444 \\
\hline $\mathrm{Cd}$ & 3920 & 0.0035 & 4230 & 0.0038 & 4370 & 0.0039 \\
\hline F & NA & 0.43 & NA & 0.63 & NA & 0.59 \\
\hline $\mathrm{Fe}$ & 247 & 0.0044 & 317 & 0.0057 & 298 & 0.0053 \\
\hline Nitrate & NA & 1.87 & NA & 4.49 & NA & 6.91 \\
\hline $\mathrm{K}$ & 850 & 0.022 & 780 & 0.020 & 790 & 0.020 \\
\hline $\mathrm{Na}$ & 3600 & 0.157 & 3500 & 0.152 & 3400 & 0.147 \\
\hline $\mathrm{Sr}$ & 22.0 & $2.5 \mathrm{E}-4$ & 23.1 & 2.6E-4 & 21.7 & $2.5 \mathrm{E}-4$ \\
\hline $\mathrm{Zr}$ & 7610 & 0.083 & 12800 & 0.140 & 12600 & 0.138 \\
\hline Solids & \multicolumn{2}{|c|}{$\begin{array}{l}\text { Majors: } \mathrm{CaF}_{2} \text { and } \\
\mathrm{Ca}_{0.15} \mathrm{Zr}_{0.85} \mathrm{O}_{1.85} \\
\text { Minors: } \\
\text { Unidentified }\end{array}$} & \multicolumn{2}{|c|}{$\begin{array}{l}\text { Majors: } \mathrm{CaF}_{2} \\
\text { Minors: } \\
\quad \mathrm{Ca}_{0.15} \mathrm{Zr}_{0.85} \mathrm{O}_{1.85}\end{array}$} & \multicolumn{2}{|c|}{$\begin{array}{l}\text { Majors: } \mathrm{CaF}_{2} \\
\text { Minors: } \\
\mathrm{Ca}_{0.15} \mathrm{Zr}_{0.85} \mathrm{O}_{1.85}\end{array}$} \\
\hline
\end{tabular}

NA $=$ Not Applicable 
Run \#64 pilot plant calcine is a $\mathrm{Zr} / \mathrm{Na}$ blend. Liquid dissolver and UDS samples were submitted only for the $5 \underline{\mathrm{M}} \mathrm{HNO}_{3}$ dissolution. The analytical results are shown in Table 11. The major liquid components are $\mathrm{Zr}, \mathrm{Ca}, \mathrm{Al}, \mathrm{Na}$, and $\mathrm{F}$. It was indicated in Table 5 that $92.33 \mathrm{wt}$. \% of this particular calcine dissolved in $5 \underline{\mathrm{M}}$ nitric acid. Roughly 1.88 moles of acid where consumed per gram of calcine in the dissolution process. The UDS analysis indicates the predominate residual in the solids is $\mathrm{CaF}_{2}$, which is difficult to dissolve.

Table 11. Chemical analysis of dissolved Runs \#64 \& \#1027 pilot plant calcines and UDS.

\begin{tabular}{|c|c|c|c|c|}
\hline \multirow{3}{*}{$\begin{array}{c}\text { Dissolvent } \\
\text { Element }\end{array}$} & \multicolumn{2}{|c|}{$\begin{array}{c}\text { Run \#64 } \\
\text { Calcine }\end{array}$} & \multicolumn{2}{|c|}{$\begin{array}{c}\text { Run \#1027 } \\
\text { Calcine }\end{array}$} \\
\hline & \multicolumn{2}{|c|}{$\begin{array}{c}5 \underline{\mathrm{M} H N \mathrm{HNO}_{3}} \\
(\mathrm{Log} \# 93-080512)\end{array}$} & \multicolumn{2}{|c|}{$\begin{array}{c}5 \underline{\mathrm{M} H N \mathrm{HNO}_{3}} \\
(\log \# 93-080512)\end{array}$} \\
\hline & $\mu \mathrm{g} / \mathrm{mL}$ & $\underline{\underline{\mathrm{M}}}$ & $\mu \mathrm{g} / \mathrm{mL}$ & $\underline{\underline{\mathbf{M}}}$ \\
\hline Acid & NA & 3.118 & NA & 3.243 \\
\hline $\mathrm{Al}$ & 6840 & 0.254 & 14900 & 0.552 \\
\hline B & 493 & 0.0046 & 136 & 0.0125 \\
\hline $\mathrm{Ca}$ & 20100 & 0.501 & 3690 & 0.0921 \\
\hline $\mathrm{F}$ & NA & 0.073 & NA & $<0.0026$ \\
\hline $\mathrm{Fe}$ & 371 & 0.0066 & 33.4 & $6.0 \mathrm{E}-4$ \\
\hline Nitrate & NA & 4.48 & NA & 4.62 \\
\hline$\underline{\mathrm{K}}$ & 530 & 0.014 & 20 & 5.1E-4 \\
\hline $\mathrm{Na}$ & 2300 & 0.100 & 200 & 0.0087 \\
\hline $\mathrm{Sr}$ & 65 & $7.4 \mathrm{E}-4$ & 7.42 & $8.5 \mathrm{E}-5$ \\
\hline $\mathrm{Zr}$ & 11000 & 1.21 & $<0.03$ & $<3 \mathrm{E}-7$ \\
\hline Solids & $\begin{array}{l}\text { Majors: } \mathrm{CaF} \\
\text { Minors: Uni }\end{array}$ & & jors: $\gamma-A$ & \\
\hline
\end{tabular}

$\mathrm{NA}=$ Not Applicable 
Run \#1027 pilot plant calcine is strictly of the alumina type. The analytical results from the dissolution in $5 \mathrm{M} \mathrm{HNO}_{3}$ are shown in Table 11. The primary component in the dissolver solution is of course Al. In accord with the previous calcine types, 1.75 moles of acid were consumed per gram of material dissolved. The major difference between Run \#1027 and the other calcines examined is the low weight percentage of this material which went into solution. From Table 5, 51.33 wt. \% of this calcine dissolved in $5 \underline{\mathrm{M}} \mathrm{HNO}_{3}$, with little or no difference in the amount dissolved at higher or lower acid concentrations. The reason for this phenomenon is easily explained in light of the UDS analysis. The major constituent in the undissolved solids is $\gamma$-alumina, which is virtually insoluble in mineral acids, including $\mathrm{HNO}_{3}$. It is anticipated that actual radionuclide-containing WCF Al calcines will not contain the acid insoluble $\alpha$ - or $\gamma$-Al phases [2]. This phenomenon arises from variations in the boron and sodium content in pilot plant versus actual calcines as different concentrations of these materials will apparently inhibit the formation of the insoluble alumina phases. As a consequence, dissolution studies with Run \#1027 pilot plant calcine were discontinued. Further experimental testing with actual aluminum calcines will be required to verify their solubility in nitric acid dissolvents due to the absence of $\alpha$ - or $\gamma$-Al.

Based on the above analyses, a simplistic understanding of the calcine dissolution process is possible. The nitric acid readily attacks most metal oxides and calcium fluoride in accord with the following generalized reactions:

$$
\begin{aligned}
& \mathrm{M}_{\mathrm{x}} \mathrm{O}_{\mathrm{y}(s)}+(2 \mathrm{y}) \mathrm{H}_{(\ell)}^{+}+(2 \mathrm{y}) \mathrm{NO}_{3(\theta)}^{-} \Longleftrightarrow \mathrm{xM}^{(\mathrm{y} / 2)+}{ }_{(\theta)}+\mathrm{yH}_{2} \mathrm{O}_{(\ell)}+(2 \mathrm{y}) \mathrm{NO}_{3(\theta)}^{-} \\
& \mathrm{CaF}_{2(s)}+2 \mathrm{H}_{(\theta)}^{+}+2 \mathrm{NO}_{3(\theta)}^{-} \Longleftrightarrow \mathrm{Ca}_{(\ell)}^{2+}+2 \mathrm{~F}_{(\ell)}^{-}+2 \mathrm{H}_{(\theta)}^{+}+2 \mathrm{NO}_{3(\theta)}^{-}
\end{aligned}
$$

Many of the oxides are soluble in accord with reaction (2). The UDS analyses indicate the predominate species which appear to be less soluble are zirconium oxide $\left(\mathrm{ZrO}_{2}\right)$ and calcium stabilized zirconium oxide $\left(\mathrm{Ca}_{0.15} \mathrm{Zr}_{0.85} \mathrm{O}_{1.85}\right)$. Consequently, these components are the major constituents in the UDS. Calcium fluoride is quite insoluble and the equilibrium of reaction (3) would typically be far to the left. However, in the presence of dissolved $\mathrm{Al}$ or $\mathrm{Zr}$, the fluoride ion is "complexed", or associated with the metal cation in solution, and the equilibrium (3) is shifted to the right. The net result is an increase in the amount of $\mathrm{CaF}_{2}$ which dissolves. Small quantities of free $\mathrm{HF}$ which are liberated by reaction (3) are thus available to attack undissolved $\mathrm{ZrO}_{2}$ or $\mathrm{Al}_{2} \mathrm{O}_{3}$ and enhance the dissolution of these species. As a consequence of the interactions between $\mathrm{ZrO}_{2}, \mathrm{Al}_{2} \mathrm{O}_{3}$, and $\mathrm{CaF}_{2}$, the nature of the UDS will depend on which of these components are in stoichiometric excess and which is the limiting component. For example, if fluoride (as $\mathrm{CaF}_{2}$ ) is in excess of the $\mathrm{ZrO}_{2}$ and $\mathrm{Al}_{2} \mathrm{O}_{3}$, it is likely these materials would be largely dissolved and $\mathrm{CaF}_{2}$ will remain in the UDS. Conversely, for excess $\mathrm{ZrO}_{2}$ and/or $\mathrm{Al}_{2} \mathrm{O}_{3}$, much of the $\mathrm{CaF}_{2}$ would be dissolved and the UDS would contain substantial quantities of the aluminum and zirconium oxides.

In accord with the analytical data, the $\mathrm{Zr}$ calcine types studied (Run \#17, \#64, and \#74) consistently consume approximately 2 moles of "free" acid $\left(\mathrm{H}^{+}\right)$per gram of calcine dissolved. For the alumina calcine type studied (Run \#20), the amount of free acid consumed is slightly 
higher, $\sim 2.5$ moles $\mathrm{H}^{+}$per gram of calcine. These results indicate kinetic or equilibrium limitations are approached at these acid consumptions per gram of calcine dissolved, and the dissolutions using $2 \underline{\mathrm{M}} \mathrm{HNO}_{3}$ where substaintially reduced due to this barrier. For the dissolutions in $5 \underline{\mathrm{M}}$ or $8 \underline{\mathrm{M} \mathrm{HNO}}$, an excess $\mathrm{H}^{+}$concentration was always observed. This explains the lack of increased dissolution with increased nitric acid concentrations.

Although not specifically studied, results of the statistical experiments indicate that the specification of acid concentration and the acid to calcine ratio is redundant. It may be more appropriate to specify the moles of acid required for dissolution per gram of calcine; therefore, the acid concentration and the acid/calcine ratio could be adjusted accordingly rather than independently. Further study in this area is suggested.

\section{Conclusions}

Based on studies with major types of $\mathrm{Zr}, \mathrm{Al}$, and $\mathrm{Na}$ blends of pilot plant calcines, the effect of the studied process variables on the amount of calcine dissolved decreases in the order:

$$
\text { Acid/Calcine Ratio (R) }>\text { Temp.(D) }>\mathrm{HNO}_{3} \text { Conc. (A) }>\text { Diss. Time (D) }
$$

This trend ranks the importance of the four process variables and is consistent for each of the five different pilot plant calcines studied.

The following conditions are suitable for approximately $90 \mathrm{wt}$. \% dissolution of $\operatorname{most} \mathrm{Zr}$, $\mathrm{Al}$, or $\mathrm{Na}$ blend calcines:

- Maximum nitric acid concentration of $5 \underline{\mathrm{M}}$

- Minimum acid/calcine ratio of $10 \mathrm{~mL}$ acid/1 gram calcine

- Minimum dissolution temperature of $90^{\circ} \mathrm{C}$

- Minimum dissolution time of 30 minutes

The notable exception is in the pilot plant $\mathrm{Al}$ calcines which contain large amounts of $\gamma$ - $\mathrm{Al}$ (and probably $\alpha-\mathrm{Al}$ ). It may be possible to combine the first two conditions and specify only the moles of acid required per weight calcine dissolved. Slightly more acid is anticipated to be required for dissolution of alumina calcine types than for the zirconia calcine types.

Dissolution experiments with actual radionuclide-containing calcines are mandatory to answer a number of different questions pertaining to large scale dissolution and the subsequent aqueous separations. For example, the extent of radionuclide dissolution must be determined at postulated process conditions to define the activity in the aqueous feed and the undissolved solids. One concern in this regard involves "high-fired" $\mathrm{PuO}_{2}$, which may be present in the calcine, and is largely insoluble in nitric acid. Consequently, most of the $\mathrm{Pu}$ would remain in the undissolved solids after calcine dissolution. Any similar behavior of other radionuclides must be 
determined for full characterization of the dissolver effluent. The radionuclide content of the aqueous feed directly impacts downstream separation processes; undissolved solids activity defines necessary disposal criteria as high-level or low-level waste. A secondary consideration revolves around the determination of the alumina phase present in the radioactive $\mathrm{Al}$ calcine types. This knowledge is of key importance to the dissolution process since $\alpha-$ and $\gamma-\mathrm{Al}$ are particularly insoluble in acidic media.

Finally, there appears to be no advantage for using HF in the initial dissolver solution as the amount of UDS is increased. The use of HF may have potential as applied to dissolution of the undissolved solids, or "heel", from the initial (and perhaps subsequent) dissolution process. In a large scale process utilizing batch or semi-continuous dissolutions, it is of fundamental importance to determine if and how much of a heel will build in the process equipment. Secondly, it is necessary to examine methods of "heel out" should the UDS build in the dissolver. Further work in this area is currently being performed with pilot plant calcines to provide such information. 


\section{PART II: FEED STABILITY}

\section{Purpose \& Scope}

The feed solution for aqueous processes designed to separate radionuclides from calcine will be comprised of calcine dissolved in nitric acid. It is imperative that the feed solution be stable with respect to precipitation of dissolved calcine matrix components. Precipitation of feed components may result in removal of target radionuclides from the solution matrix. In addition, liquid/liquid separation processes require the absence of insoluble precipitate. Therefore, an understanding of feed stability is an integral part of the development of post processing options.

Feed stability in terms of precipitation manifests itself in three forms. First, the original solution may be concentrated in certain compounds enough to force precipitation. Second, temperature extremes may alter equilibria and cause precipitation. Third, the liquid may evaporate to an extent where compounds are sufficiently concentrated to cause precipitation identical to that mentioned above.

The proposed dissolution schemes require high temperature and short dissolution time. If the dissolver solutions are allowed to cool and equilibrate it might be thermodynamically favorable for some constituents in the feed solution to precipitate. The dissolution experiments for pilot plant calcines resolved that $5 \underline{\mathrm{M}}$ nitric acid, temperatures of 90 to $100{ }^{\circ} \mathrm{C}$, dissolution times of 30 minutes and an acid to calcine ratio of $10 \mathrm{~mL}$ of acid per gram of calcine is sufficient to dissolve greater than $90 \mathrm{wt}$. \% of several representative calcine types. It is necessary to determine whether the dissolved calcine solutions prepared with this "recipe" are sufficiently stable with respect to precipitate formation.

The mechanism for precipitation in solution is governed by the solubility product, $\mathrm{K}_{\mathrm{sp}}$ of the precipitating species. When $\mathrm{K}_{\mathrm{sp}}$ is exceeded, that component will precipitate out of solution. The solubility product is a function of concentration, temperature and solution activity at equilibrium. A precipitate was observed in several dissolved calcine solutions, most noteably in dissolved Run \#74 pilot plant calcine solutions. Analysis indicated the precipitate was $\mathrm{CaSO}_{4}$, which in solid form is hydrated $\mathrm{CaSO}_{4} \cdot 2 \mathrm{H}_{2} \mathrm{O}$, or gypsum. Calcium and sulfur appear in nearly all pilot plant calcines (Run \#1027 is the most notable exception) as $\mathrm{CaO}, \mathrm{CaF}_{2}, \mathrm{CdSO}_{4}$, and $\mathrm{K}_{2} \mathrm{SO}_{4}$. These are also constituents in most radioactive calcine types. Therefore, gypsum was the focus for feed stability in this work. Experiments detailed in the following pages more clearly outline the feed stability of calcium sulfate in Run \#74 pilot plant calcine dissolution liquid. The significance of these results to the dissolution liquids of other pilot plant calcines and actual radioactive zirconia and alumina calcines are presented.

Consequently, the scope of this study focussed on evaluating:

- Stability of dissolved pilot plant calcine solutions (results extended to radioactive calcines) with regards to gypsum precipitation.

- Temperature effects on stability of the dissolution liquid.

- Stability of the dissolution liquid during evaporation processes. 


\section{Theory}

The important interactions for the stability of calcium sulfate in solution are:

$$
\begin{aligned}
\mathrm{CaSO}_{4(\mathrm{~s})} & \rightleftharpoons \mathrm{Ca}_{(\mathrm{aq})}{ }^{2+}+\mathrm{SO}_{4}{ }^{2-}(\mathrm{aq}) \\
\mathrm{HSO}_{4}^{-}{ }_{(\mathrm{aq})} & \rightleftharpoons \mathrm{H}^{+}{ }_{(\mathrm{aq})}+\mathrm{SO}_{4}{ }^{2-}{ }_{(\mathrm{aq})}
\end{aligned}
$$

Both interactions are dissociation reactions, one for calcium sulfate $\left(\mathrm{K}_{\mathrm{sp}}\right)$, the other for monoprotic sulfuric acid $\left(\mathrm{K}_{\mathrm{A} 2}\right)$. The second reaction consumes sulfate ions and affects the final equilibrium of the calcium sulfate.

The solubility product constant for calcium sulfate is defined as:

$$
\mathrm{K}_{\mathrm{sp}}=\left[\mathrm{Ca}^{2+}\right]\left[\mathrm{SO}_{4}{ }^{2-}\right]
$$

The value of the solubility product constant for calcium sulfate in water is $7.10 \times 10^{-5}$ [8]. Due to the activity effects of the highly diverse constituents in the dissolver solution, the solubility product will vary around this number.

The quantity of concern when evaluating the solubility product for feed stability is the solubility quotient, $Q$. The solubility quotient has the same form as the solubility product, but the concentrations need not have their equilibrium values [9]. If the solubility product is known or can be estimated, and the solubility quotient can be determined for a solution, the stability of the solution can be evaluated by comparing the two values. A calculated solubility quotient above the solubility product indicates that component will precipitate from solution. Conversely, a solubility quotient below the solubility product insures that the solution will be stable, i.e., precipitation will not occur.

In order to better quantify the solubility product and the behavior of the solubility quotient, a series of experiments were performed varying the calcium, sulfate, and acid concentrations in Run \#74 dissolver solutions. This was achieved by varying the acid solution volume to calcine mass ratio, hereafter referred to as acid/calcine ratio, and observing whether precipitate forms. The procedure used in concentrating the solutions was straightforward; a reduced volume of acid was added to the same sample size of calcine. While both percent dissolution and resulting solution volume are reduced, the decrease in percent dissolution is not greatly reduced (in accord with the results presented in the first part of this report) and the primary result is an increase in the concentration of dissolved species. A proportional decrease in free acid is also realized. 


\section{Experimental Procedure}

The experimental procedure for examining feed stability is outlined below. Several aspects of feed stability were tested, each requiring different procedures. These are described individually.

\section{Dissolution}

A procedure nearly identical to that used in the bench scale dissolution experiments was used to produce the dissolver solution on which stability was observed. This served to insure that feed stability would be representative of actual dissolver concentrations.

(1) Various weights of Run \#74 calcine necessary to produce the proper acid/calcine ratio were weighed into a beaker. A 80:20 wt\% mixture of product to fines was used in all experiments. Note this is a different ratio of product to fines than was previously used $(60: 40 \mathrm{wt} \%)$ and is more representative of expected proportions in actual calcines.

(2) A magnetic stir bar was added followed by $30 \mathrm{~mL}$ of $5 \mathrm{M}$ acid preheated to near boiling. The beaker was covered with a watch glass, placed in a preheated water bath and set on a hot plate with agitation.

(3) The experiments ran for 30 minutes at a temperature of approximately $90-100^{\circ} \mathrm{C}$. The beaker was removed and the bulk of the suspended solids allowed to settle to the bottom of the beaker for approximately 10 minutes.

(4) The clarified liquid was pipetted off the top of the settled undissolved solids (UDS) and gravity filtered through 542 Whatman filters. The filters removed all particles down to 2.7 micron size. The solution was transferred to vials and centrifuged to remove the last of the UDS. The final dissolver solution was transferred to a marked vial for feed stability observations. All dissolver solutions were approximately $17 \mathrm{~mL}$ in volume.

(5) The UDS from centrifuging was combined with the UDS from step (4) in the Whatman 542 filters. The filters were water rinsed and ashed at $500^{\circ} \mathrm{C}$ for 2 hours.

(6) The UDS were weighed to determine percent dissolution.

\section{Feed Stability}

(1) The dissolver solution was allowed to stand at room temperature for at least 140 hours before the solutions were filtered for precipitate. All solutions were re-filtered periodically if additional precipitate appeared.

(2) The dissolver solution was filtered through Whatman 542 filter paper under vacuum and the solution transferred to a separate container prior to water washing. Vacuum filtration 
reduced the contact time between the solid gypsum and the water wash to help alleviate further solubility during the wash step.

(3) The filters were ashed at $500^{\circ} \mathrm{C}$ for 2 hours and weighed to determine solids concentration.

(4) The dissolver solution was returned to its original vial and visually monitored for further instability. The procedure was repeated for subsequent precipitation.

Note: Although the melting point of gypsum is reported to be $128^{\circ} \mathrm{C}$ [8], the actual weight loss due to gypsum volatilization was negligible. The same source reports a boiling point of $1100^{\circ} \mathrm{C}$, well above temperatures inside the furnace. Losses were considered negligible and experiments investigating sample loss showed no tendency for gypsum volatilization.

\section{Temperature Varied Feed Stability}

(1) A $100 \mathrm{~g}$ sample (60:40 product to fines ratio) of Run \#74 pilot plant calcine was dissolved in $1000 \mathrm{~mL}$ of $5 \mathrm{M}$ nitric acid with a dissolution time of 30 minutes at a temperature of $90-100^{\circ} \mathrm{C}$ in accord with the results of the dissolution study.

(2) The resulting solution was vacuum filtered through Whatman 542 filter paper to remove the undissolved solids (UDS). This liquid was the feed used for the temperature dependent stability studies.

(3) Appropriately sized aliquots (40 to $60 \mathrm{~mL}$ ) were placed in teflon sample containers. These samples were stored at room temperature or in an oven at $67^{\circ} \mathrm{C}$.

(4) At various times, the samples were filtered and the solids concentration (in $\mathrm{g} / \mathrm{l}$ ) determined as a function of time. Samples were filtered through Whatman 542 and the filter paper ashed in a furnace at $500^{\circ} \mathrm{C}$ for 2 hours.

\section{Evaporation}

(1) Solutions from previous dissolution experiments with Run \#17 pilot plant calcine were used in this experiment. They were prepared with a half hour dissolution time, a ratio of $10 \mathrm{~mL}$ of $8 \underline{\mathrm{M}}$ acid to one gram of calcine, and a temperature of $90-100^{\circ} \mathrm{C}$.

(2) Sample aliquots of $40 \mathrm{~mL}$ were evaporated to a lower, predetermined volume on a hot plate using a water bath.

(3) The evaporated solution was gravity filtered through Whatman 542 filter paper. The filters were ashed at $500^{\circ} \mathrm{C}$ for 2 hours to determine weight percent solids. 


\section{Results \& Discussion}

The results of the constant temperature feed stability experiments offer conclusive evidence regarding the feed stability of Run \#74 dissolver solutions. Run \#74 pilot plant calcine is an appropriate test calcine for feed stability due to the high elemental calcium and sulfate content. The compounds of interest are readily concentrated in solution making it much easier to pinpoint the solubility product constant and conduct experiments by using lower acid/calcine ratios. Experiments at substantially reduced ratios $(<\sim 4)$ are difficult to perform as large amounts of UDS complicate filtration. The results of the constant temperature stability studies with dissolved Run \#74 pilot plant calcine solutions are shown in Figure 2.

At acid/calcine ratios of 3 through $7 \mathrm{~g} / \mathrm{ml}$, precipitate consistently forms within 24 hours and continues to fall out of solution for 12 to 15 days. Seeding the solution with unfiltered UDS causes precipitation much earlier, generally in under 8 hours. The precipitate appears as white flakes. If allowed to stand during precipitation, the solids adhere to one another and break up only with severe agitation. At an acid/calcine ratio of 8 , no measurable solids were formed. It is believed that at this acid /calcine ratio, the dissolution liquid is saturated and just equal to or

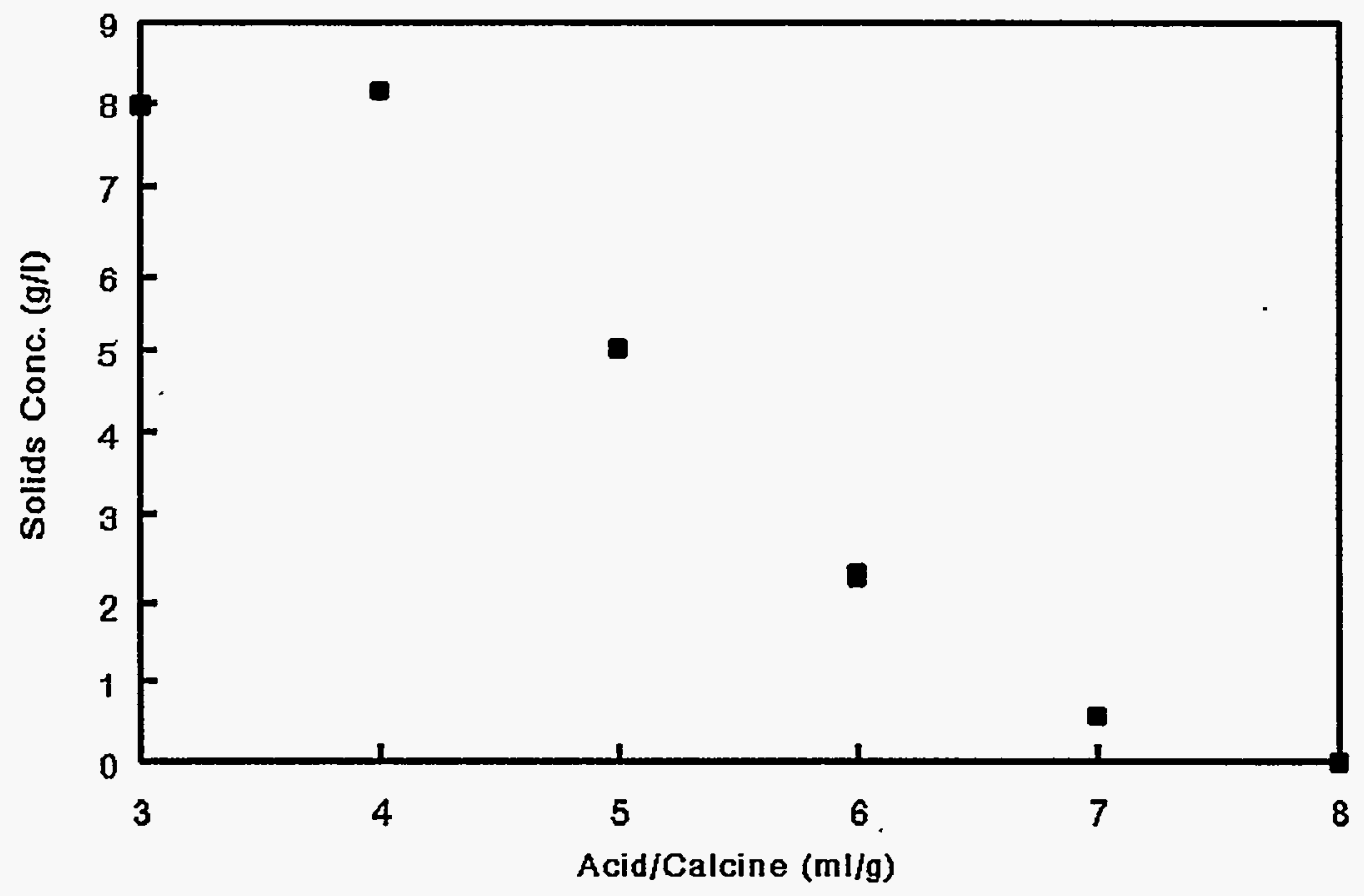

Figure 2. Precipitate concentration found in solutions of Run \#74 dissolved in $5 \underline{\mathrm{M}}$ acid. 
slightly below the solubility product of calcium sulfate. Solids formation is subtantially reduced at ratios of 5 and 6 . A precipitate concentration of only $0.55 \mathrm{~g} / \mathrm{l}$ is present at an acid to calcine ratio of 7 .

In order to generalize the feed stability tests on Run \#74 to all types of calcine, including expectations for actual radioactive calcine, it is necessary to determine the solubility product constant for calcium sulfate in the dissolved calcine solutions. Two equilibrated dissolver solutions were analyzed for calcium and sulfate concentrations. After the effect of acid association between $\mathrm{H}^{+}$and sulfate is estimated (reaction 6) through $\mathrm{K}_{\mathrm{A} 2}$ for sulfuric acid, an estimation of the solubility product is possible. The results are shown in Table 12.

This $\mathrm{K}_{\mathrm{sp}}$ is higher than that for calcium sulfate in water, $\mathrm{K}_{\mathrm{sp}}=7.10 \times 10^{-5}$, but is a better indication of $\mathrm{CaSO}_{4}$ solubility since it was found under conditions similar to that used for calcine dissolution. It is likely that the disagreement stems from neglecting activities in calculating the experimental $\mathrm{K}_{\mathrm{sp}}$. In addition, temperatures identical to those for $\mathrm{K}_{\mathrm{sp}}$ values in the literature were not maintained, varying anywhere from 0 to $5^{\circ} \mathrm{C}$ above the $25^{\circ} \mathrm{C}$ literature conditions.

The experimental value of the solubility product can be compared to solubility quotients for various dissolver solutions. Since direct analysis for calcium and sulfate in all conceivable solutions is not practical, a method for predicting $Q$ was derived. The $Q$ value is predicted from weight percent dissolution, acid concentration and elemental analysis of solid calcines. Since all of this information is available for radioactive calcines under certain conditions, the solubility quotient can be calculated for them as well.

The equation for $Q$ is,

$$
\mathrm{Q}=\left[\mathrm{Ca}^{2+}\right]\left[\mathrm{SO}_{4}{ }^{2-}\right]
$$

It is similar to that for $\mathrm{K}_{\mathrm{sp}}$ but the concentrations are those found immediately after dissolution, i.e. non-equilibrium values. The calcium ion concentration was predicted by assuming that the amount of elemental calcium dissolved is equal to that of the fraction of the pilot plant calcine sample that dissolved. This is reasoned by the fact that upon analysis of the undissolved solids of several calcine types, $\mathrm{CaF}_{2}$ and $\mathrm{CaO}$ are generally a major component. The prediction compares favorably to analyses that were made for calcium in a group of experiments. Figure 3 is a graphical comparison of the actual and predicted values.

Table 12. Solubility product estimation for calcium sulfate in calcine dissolution liquid.

\begin{tabular}{|l|l|c|}
\hline Experiment & \multicolumn{1}{|c|}{$\left[\mathrm{Ca}^{2+}\right]\left[\mathrm{SO}_{4}{ }^{2-}\right]$} & Average $\mathrm{K}_{\mathrm{sp}}$ observed \\
\hline Run \#74 Acid/Calcine $=6$ & $1.46 \times 10^{-4}$ & \multirow{2}{*}{$1.46 \times 10^{-4}$} \\
\cline { 1 - 2 } Run \#74 Acid/Calcine $=8$ & $1.47 \times 10^{-4}$ & \\
\hline
\end{tabular}


Figure 3. Calcium ion prediction based on elemental composition and percent dissolution for Run \#74 dissolution liquid.

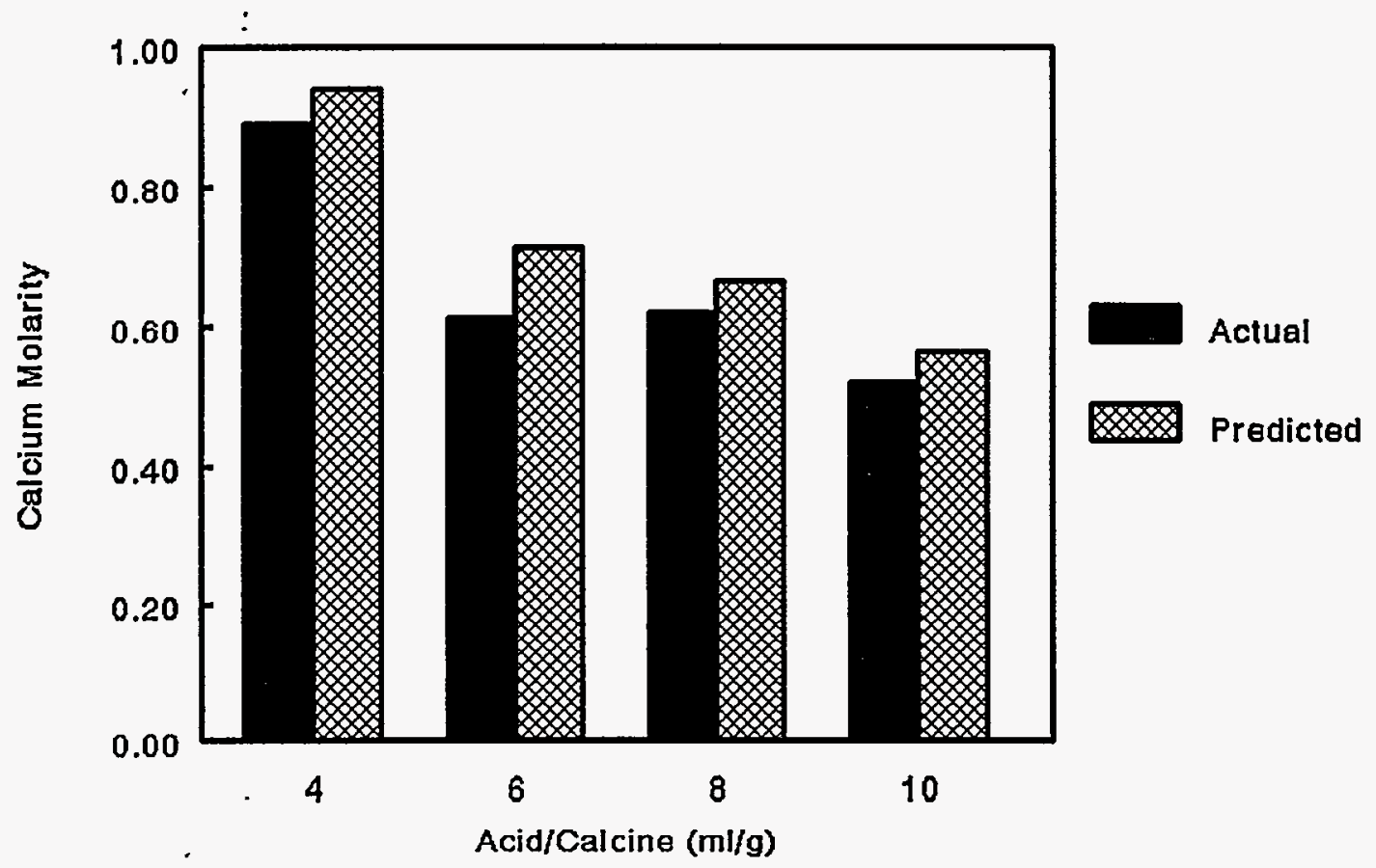

It is apparent from Figure 3 that the predicted values are fairly good, but consistently higher than the actual actual values. Differences are attributed to analytical and experimental errors or the assumption that the calcium dissolution directly related to percent of calcine dissolution. Note, however, that nearly complete dissolution of the calcine does not require an estimate of a dissolution rate of calcium. This makes the original prediction much simpler and the values more accurate, particularly at higher acid/calcine ratios. The final predictions focussed on this area since it is proposed as the most probable dissolution ratio.

The sulfate ion concentration prediction is complicated by the side reaction of monoprotic sulfuric acid. To predict sulfate ion concentration, it is first assumed that all the elemental sulfur dissolves regardless of the extent of dissolution. This is warranted in that sulfates rarely appear in the analyses of the undissolved solids. The prediction is also compared to that of actual analyses in Figure 4. 
Figure 4. Elemental sulfur ion prediction based on elemental composition and percent dissolution for Run \#74 dissolution liquid.

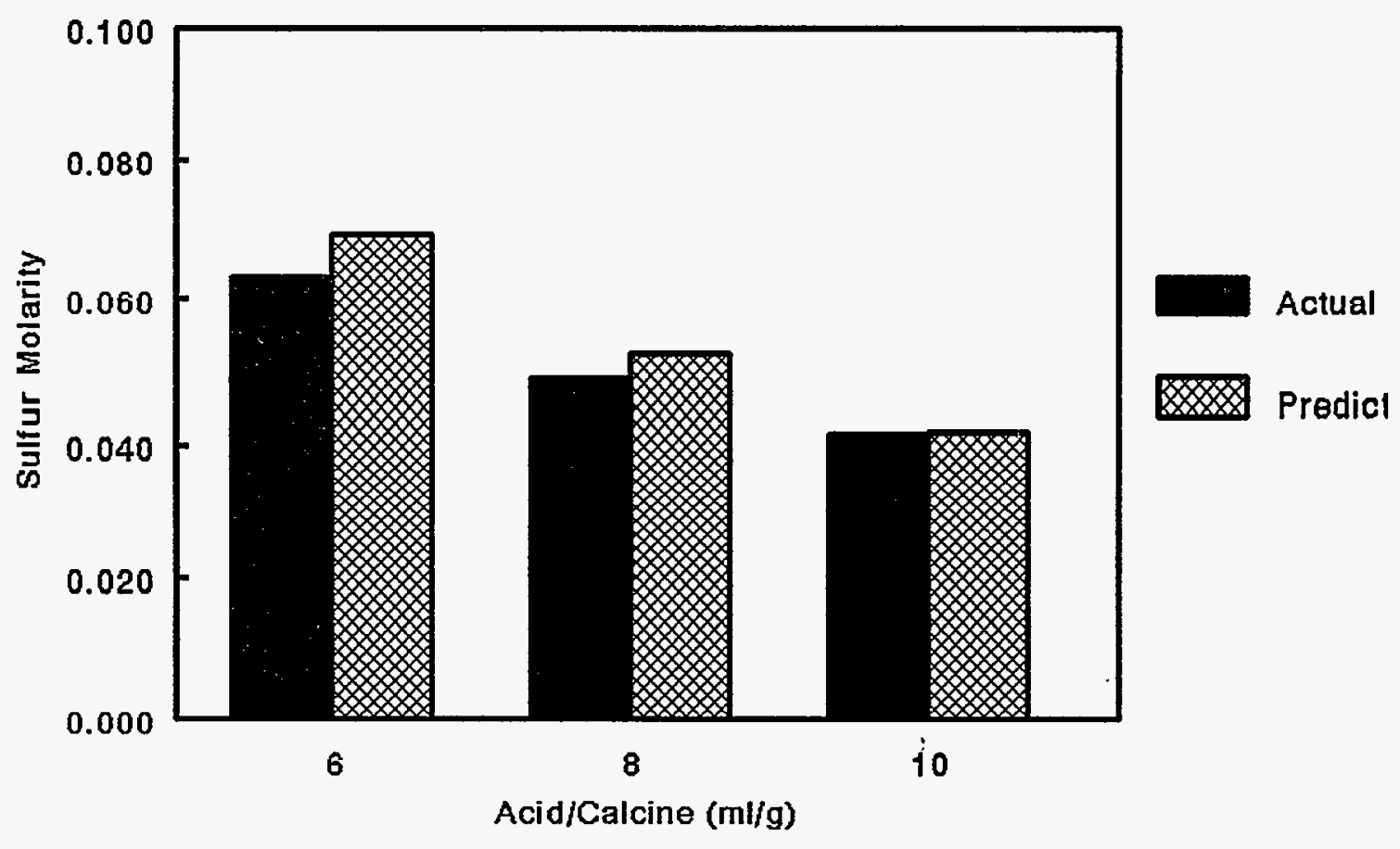

The trend observed in Figure 3 is repeated here. It should be noted that the literature sulfur composition had to be correlated with the new analyses as a $1.8 \%$ elemental sulfur content yielded numbers which were consistently low [8]. A sulfur mass balance based on chemical analysis indicates that $4 \mathrm{wt} \%$ elemental sulfur in Run \#74 is more accurate.

After arriving at a sulfur concentration it is then assumed that all the sulfur exists in the form of sulfate ions in solution. Using the acid equilibrium constant, the amount of free sulfate is calculated. The form of the equation is:

$$
\mathrm{K}_{\mathrm{A} 2}=\frac{\left[\mathrm{H}^{+}\right]\left[\mathrm{SO}_{4}{ }^{2-}\right]}{\left[\mathrm{HSO}_{4}^{-}\right]}
$$


Acid concentration can be determined experimentally by titration and the $\mathrm{K}_{\mathrm{A} 2}$ is tabulated in the literature [8]. The second equation necessary is a mass balance on elemental sulfur:

$$
[\mathrm{S}]=\left[\mathrm{SO}_{4}^{2-}\right]+\left[\mathrm{HSO}_{4}^{-}\right]
$$

The value [S] is an elemental concentration of sulfur in solution. This unconventional term is convenient for calculation but it is not to be implied that elemental sulfur is chemically present in the solution. The manipulation of equations (8) and (9) leads to the following relationship:

$$
\mathrm{K}_{\mathrm{A} 2}=\frac{\left[\mathrm{H}^{+}\right]\left[\mathrm{SO}_{4}{ }^{2-}\right]}{\left([\mathrm{S}]-\left[\mathrm{SO}_{4}{ }^{2-}\right]\right)}
$$

Combination and rearrangement of equations (9) and (10) yields the desired result:

$$
\left[\mathrm{SO}_{4}{ }^{2-}\right]=\frac{\mathrm{K}_{\mathrm{A} 2} *[\mathrm{~S}]}{\left(\mathrm{K}_{\mathrm{A} 2}+\left[\mathrm{H}^{+}\right]\right)}
$$

The expression for $\mathrm{Q}$ follows as a product of the two ions and can be calculated using equations (7) and (11), both derived only from percent dissolution and acid concentration:

$$
\mathrm{Q}=\left[\mathrm{Ca}^{2+}\right] \frac{\mathrm{K}_{\mathrm{A} 2} *[\mathrm{~S}]}{\left(\mathrm{K}_{\mathrm{A} 2}+\left[\mathrm{H}^{+}\right]\right)}
$$

Note that the solubility quotient is proportional to calcium and sulfate ion concentration but inversely proportional to acid concentration. Thus, at higher acid concentrations, the solution will inherently be more stable. These observations can be used as future avenues to ensure feed stability should it present a problem.

Equation (12) was used to calculate $Q$ from the experimental data with dissolved Run \#74 calcine. These results are graphed against the solubility product in Figure 5. The graph shows that the acid/calcine ratio of 8 is the threshold of feed stability as was previously shown in Figure 2. Beyond acid to calcine ratios of $8, Q$ is at or below the solubility product and the resulting solution is stable with regards to $\mathrm{CaSO}_{4}$ precipitation. 
Figure 5. Solubility quotients for Run \#74 calcine dissolved in $5 \underline{\mathrm{M}}$ acid.

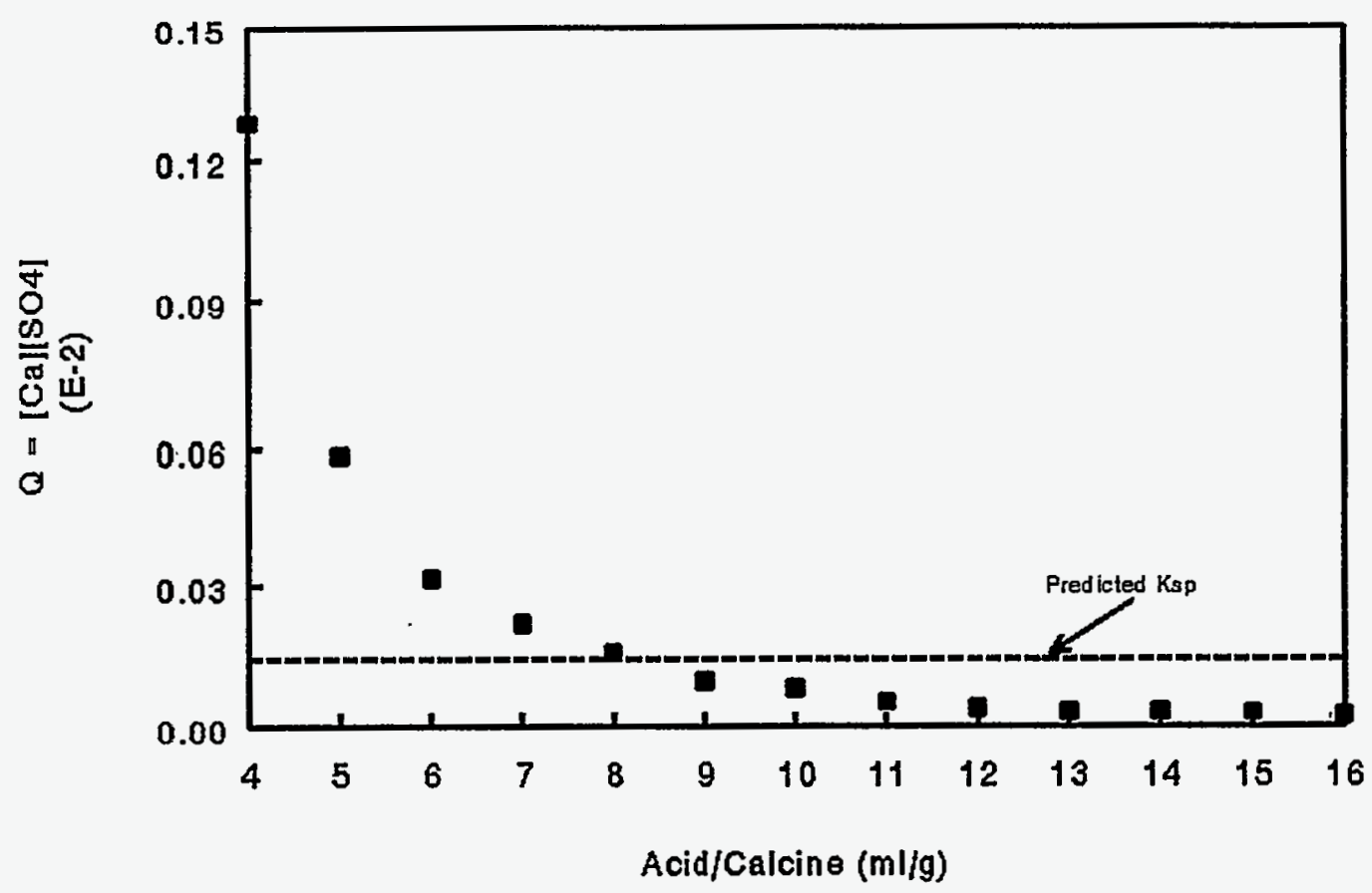

The next step is to generalize this approach to all calcines, including radioactive zirconia and alumina calcines, and predict the feed stability of the anticipated dissolver solutions.

Analytical data on the chemical composition of the dissolver solutions from Runs \#74, \#17, \#64, and \#1027 pilot plant calcines and zirconia and alumina radioactive calcines have been collected. The dissolver solutions were all prepared using the "recipe" developed earlier; 1 gram of calcine per $10 \mathrm{~mL}$ of $5 \underline{\mathrm{M}}$ nitric acid, half hour dissolution time, and dissolution temperature of 90 $100^{\circ} \mathrm{C}$. The data were used to predict feed stability for the resulting solutions. The calcium data for the predictions are directly from analysis of the dissolver solution. Unfortunately, the sulfate composition was not determined at the time. This value was calculated by way of the technique outlined above and data provided from literature sources on elemental compositions of solid calcine $[10,11]$. The results of these predictions are shown in Figure 6. 
Figure 6. Predicted feed stability of dissolver solutions. Calcines dissolved in $10 \mathrm{~mL}$ of 5 $\underline{\mathrm{M}}$ nitric acid per gram of calcine for 30 minutes at temperatures of $90-100^{\circ} \mathrm{C}$.

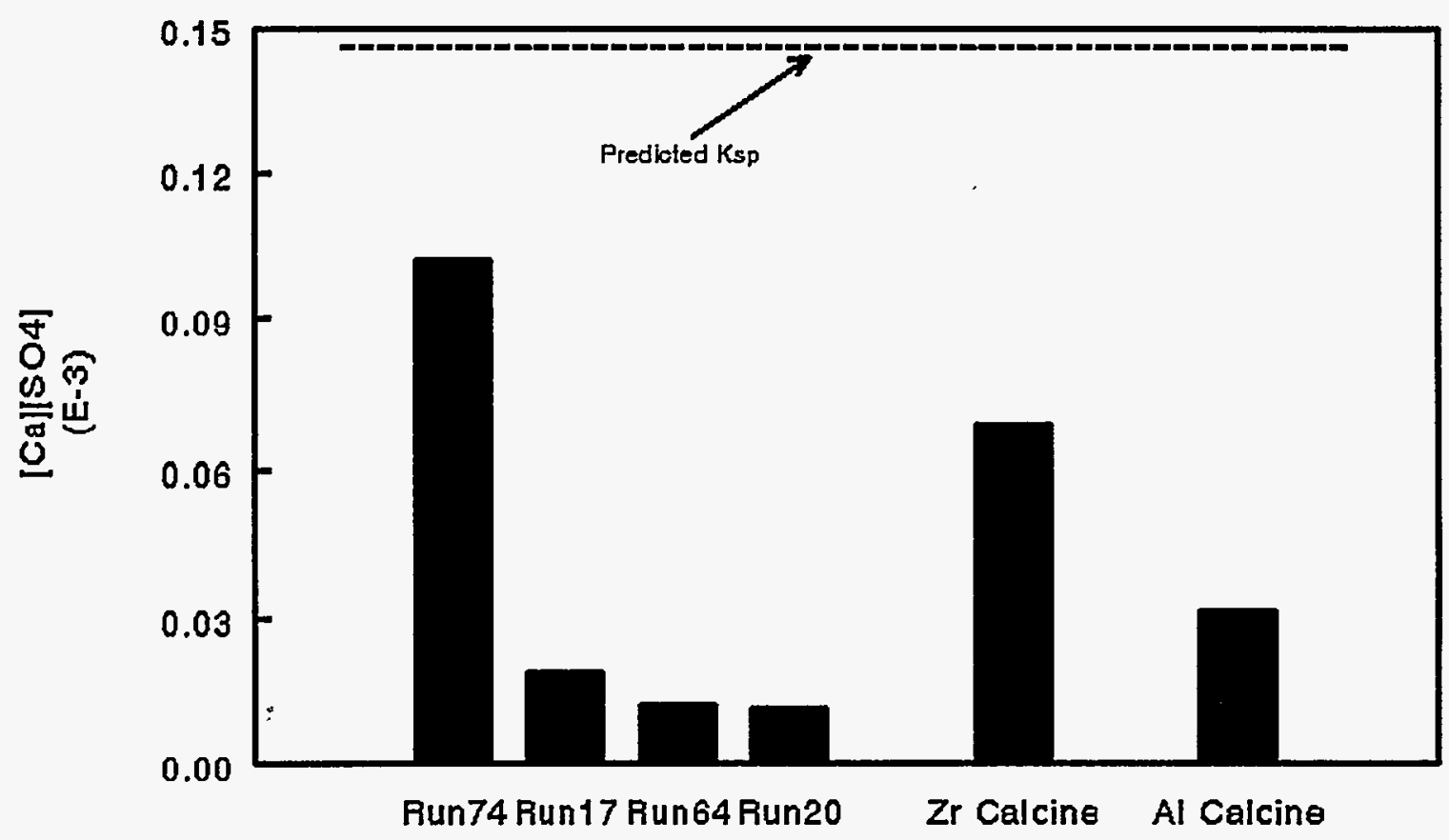

It is apparent from Figure 6 that feed stability is not a concern at the conditions proposed for any of the calcine types considered. Run \#74 dissolution liquid poses the greatest danger to feed stability with zirconia based radioactive calcine a close second. Both are nearer the solubility product simply because they have high elemental sulfur and calcium content. Run \#1027 does not appear on the diagram because it has no sulfur containing compounds.

The possibility exists that a process could be designed to dissolve nearly all the calcine. If such an efficient dissolution is achieved, the equilibrium product of the calcium and sulfate ion is predicted to still be below the limit of solubility. In other words, if all the calcium and sulfur in the above calcines were in the dissolver solution, the liquid would still be stable with regards to precipitation. The important exception would be if the acid concentration were reduced drastically without diluting the solution. This condition would lead to instability.

The data and predictions suggest that feed stability is flexible to variations inherent in a scaleup of the dissolution process. Even to the extent of a steady state mixing and dissolution 
process, feed stability seems to be of small concern. As long as the acid/calcine ratios are reasonably near 10 with an acid dissolvent concentration near $5 \underline{\mathrm{M} \mathrm{HNO}}$, this portion of the study ensures that precipitate will not be found in the dissolution liquid.

The temperature dependence of the dissolution liquid was studied. Although large temperature variations are not foreseen for the process, some analysis of this parameter is warranted. An experiment with Run \#74 calcine indicates the $\mathrm{CaSO}_{4}$ solubility product increases with temperature. The results are shown graphically in Figure 7.

$\mathrm{A} \mathrm{K}_{\mathrm{sp}}$ greater than $1.46 \times 10^{-4}$ is projected at the foreseeable process temperatures. This being the case, the study outlined previously describes the limit of adverse temperature effects on precipitation. Room temperature is envisioned to be the lowest temperature encountered in the system. Although temperatures between 10 and $15^{\circ} \mathrm{C}$ have been reported for similar process conditions at ICPP, the combined effects of thermal radiation from cesium and strontium with the inherent heat generation of the process equipment ensure that temperatures will rarely fall below room temperature. Therefore, a more stable feed is predicted for temperatures beyond those analyzed in this study.

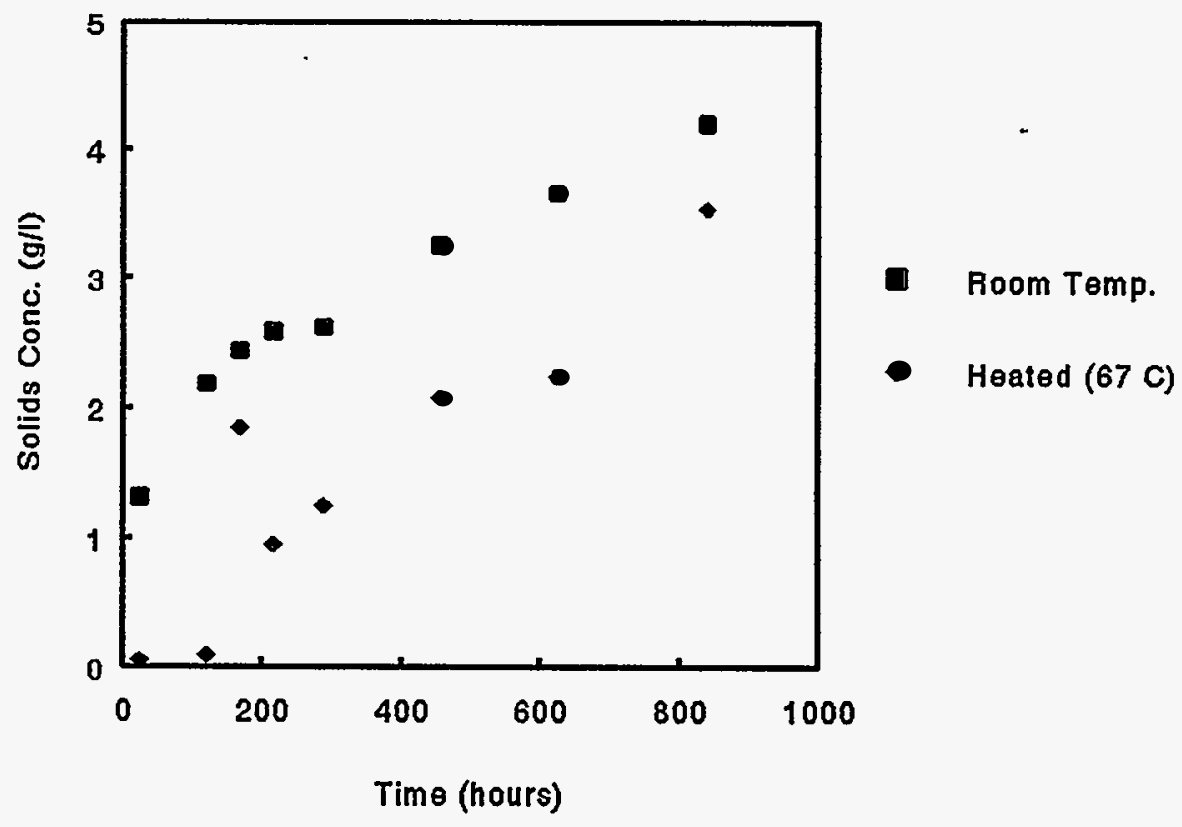

Figure 7. Temperature dependence of $\mathrm{CaSO}_{4}$ solubility. Data gathered from Run \#74 calcine dissolved at $10 \mathrm{~mL} 2 \underline{\mathrm{M}}$ nitric acid per gram calcine, $90-100^{\circ} \mathrm{C}$, and 30 minutes dissolution time. 
An extension of this study was the analysis of the solutions under evaporation conditions. Evaporation concentrates the three components of interest to feed stability: acid, sulfate, and calcium ions, as well as others not as prone to precipitation in the liquid. From a thermodynamic standpoint, this results in upsetting the equilibrium and forcing a new equilibrium. At high enough volume reduction, $\mathrm{CaF}_{2}, \mathrm{AlF}_{3}$, and $\mathrm{ZrNO}_{3}$ solids and perhaps others, begin to appear. The end result of the evaporative concentration was heavy precipitate formation. Studies show this occurs around $75 \%$ volume reduction. Figure 8 displays this tendency for Run \#17 solutions. A detailed study of this phenomenon in terms of solubility quotients was not initiated and appears unwarranted given the great amount of evaporation required for precipitation. Any volume reduction in the separation process would be incidental. Evaporation resulting in $75 \%$ reduction of volume would result in consequences of an extremely serious nature, far beyond those of feed stability.

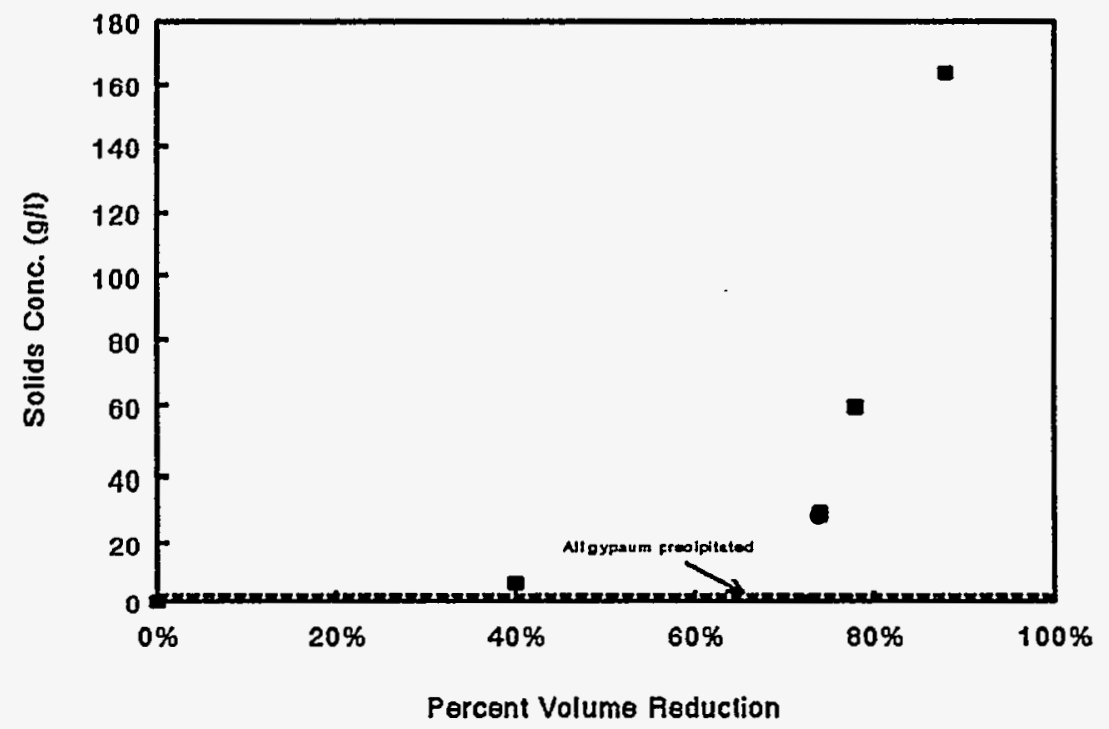

Figure 8. Effect of evaporation on feed stability. Experiments performed on Run \#17 calcine dissolved in $8 \underline{\mathrm{M}}$ nitric acid, $10 \mathrm{~mL}$ acid per gram calcine, 30 minute dissolution time at $90-100^{\circ} \mathrm{C}$. 


\section{Conclusions}

These studies with the most unstable pilot plant calcine dissolver solution, i.e. Run \#74, and additional volume reduction studies led to three major conclusions. The conditions proposed for dissolution based on results in the first part of this report are equitable to stability of Run \#74 solutions in terms of precipitation. Furthermore, with the chemical analysis of these solutions, a solubility limit can be anticipated for other dissolved calcine feed solutions. This limit, the solubility product for calcium sulfate, further suggests that all calcine dissolved under the aforementioned conditions will be stable to precipitation. The results of the study provide evidence that the actual radioactive calcine dissolution liquid is resistant to precipitation of calcium sulfate.

The envisioned process temperature ranges do not endanger solution stability regarding precipitation. In fact, conceivable temperatures present in the separation process are anticipated to be at, or above, those scrutinized in this study. Higher temperatures will enhance chemical stability of the solutions.

Finally, volume reduction due to evaporation is not a concern for feed stability.

Evaporation so severe as to cause precipitation in the solution is not envisioned in the separation processes. However, plans currently include concentrating the LLW product to $\sim 6 \underline{\mathrm{M}} \mathrm{HNO}_{3}$ by evaporation. Further work in this area is mandatory to insure precipitation will not occur during this unit operation. 


\section{REFERENCES}

[1] Mincher, B. J., TRUEX and Calcine Leaching Studies, unpublished data.

[2] Paige, B. E., "Leachability of Alumina Calcine Produced in the Idaho Waste Calcining Facility", IN-1011, July 1966.

[3] Samsel, E. G., Dissolution of Simulated AGNS Calcine Fines in Aqueous and Acidic Media, unpublished data.

[4] Butler, P. C., and D. R. Trammell, "Calcine Dissolution Experiments, Division Quarterly Progress Report July 1 - September 30, 1977", ICP-1132, October 1977.

[5] Butler, P. C., and D. R. Trammell, "Calcine Dissolution Experiments, Division Quarterly Progress Report October 1 - December 31, 1977", ICP-1141, February 1978.

[6] Box, G. E. P., W. G. Hunter, J. S. Hunter, Statistics for Experimenters, An Introduction to Design, Data Analysis, and Model Building, Chapters 9-11, John Wiley \& Sons, New York, NY, 1978.

[7] Staples, B. A., Pomiak, G. S., and Wade, E. L., "Properties of Radioactive Calcine Retrieved From The Second Calcined Solids Storage Facility At ICPP", ICP-1189, March 1979.

[8] Lide, D. R., editor, CRC Handbook of Chemistry and Physics, 73rd Edition, CRC Press, Inc., 1992-93, p.8-43.

[9] Harris, Quantitative Chemical Analysis, 1982, Arcate Book Group, p.309.

[10] Staples, B. A., Characterization of Simulated Calcines Stored in Cargo Container A, unpublished data.

[11] Berreth, J. R., "Inventories and Properties of ICPP Calcines", WINCO-1050, 1988.

[12] Tonso, J. L., Agitation Study for the Calcine Dissolution Process, unpublished data.

[13] Brewer, K. N., Herbst, R. S., Tranter, T. J., Olson, A. L., Todd, T. A., Lundholm, C. W., Goodwin, I. D., "Dissolution of Two NWCF Calcine Types: Extent of Dissolution and Characterization of Undissolved Solids", LITCO Report, In press. 